\title{
The Protection of Performer's Rights under the Copyright Law in Thailand: The Proposed Reform in the Light of the Prospective Free Trade Agreements with the United States and European Union
}

Noppanun Supasiripongchai*

Director, Intellectual Property Law Research and Development Center (IPLRDC), Faculty of Law, University of Phayao, Thailand

\begin{abstract}
This article considers the legal changes which must be made to the protection of performers' rights under the Thai Copyright Act (CA) 1994 if Thailand is going to sign the Free Trade Agreements (FTA) with the United States or the European Union that would be likely to require Thailand to ratify the WIPO Performances and Phonograms Treaty 1996 (WPPT). It argues that the current provisions of the Thai CA 1994 still fall short of the standard for the protection of performers' rights under the WPPT, the provision of the prospective FTA of the United States and that of the European Union. It recommends that Thailand must improve the provisions on the protection of performers' rights in the current Thai CA 1994 in order to provide better protection for performers' rights in Thailand and make such provisions consistent with the standard of the protection of performers' rights in the WPPT and the prospective FTAs.
\end{abstract}

Keywords: Performers' rights in Thailand; Moral rights of performers; Exclusive right of performers; Right to remuneration of performers; Digital right management for performers in Thailand; Thai copyright law

\section{Background to the Protection of Performers' Rights in Thailand}

Performers' rights are related rights or neighbouring rights which are different from copyright because the rights provided by copyright apply to authors, but related rights are the rights that belong to the performers, the producers of phonograms and broadcasting organizations in relation to their performances, phonograms and broadcasts [1]. Although related rights are different from copyright, there is nevertheless a link between them because these three categories of related rights owners are auxiliaries in the intellectual creation process since they lend their assistance to authors in the communication of their works to the public. For example, actors perform roles in a play, which are written by playwrights; or producers produce songs and music, which are written by authors and played by musicians or sung by performers. Without performers, some of these works would never be available to the public and also some of them would never be completed. For instance, many people are unable to read music and thus cannot enjoy it unless through performances of musicians and also movie or film cannot really complete without performers [2]. The skill and labour of performers is important to the public enjoyment of those art works and thus, performers should be protected against unauthorized exploration of their performances in the same way as authors of copyright works enjoy copyright.

Before the beginning of 1994, performers' rights were not recognized in Thailand. The previous Thai Copyright Act 1978 did not recognize performers' rights, but it provided protection for the rights of producers of phonograms by protecting the producer of phonogram as the copyright owners. The performers at that time had to seek protection for their rights through contract law, but these contractual rights cannot be enforced against third parties since they can be enforced only a party to the contract. The performers' rights were formally recognized for the first time in Thailand after the promulgation of the Thai Copyright Act 1994 (hereinafter CA 1994).

The protection of the performers' right under CA 1994 seems to be based on two international treaties: 1) the Rome Convention for the Protection of Performers, Producers of Phonograms and Broadcasting Organization 1961 (hereinafter the Rome Convention) [3] and 2) the Agreement of Trade-Related Aspect of Intellectual Property Rights (TRIPs Agreement). It is important to note that Thailand is a signatory to the TRIPs Agreement. Although Thailand is not a signatory to the Rome Convention, Thai legislators used the standard of the protection of performers' rights under the Rome Convention together with the TRIPs Agreement as the model for formulating the provisions on the protection of performers' right in the CA 1994. At first, the legislators had no intention to use the standard of the Rome Convention because the main purpose of the replacement of the previous CA 1978 with the CA 1994 is to implement the Thailand's obligation under the TRIPs Agreement. But, the pressure from performers association and other entertainment associations lead to the incorporation of the standard of the protection of performers' rights under the Rome Convention into the CA 1994. However, although the protection of performers' right under the Thai CA 1994 meets the standard of the protection under the Rome Convention 1961 and the TRIPs Agreement, it falls short of the standard of the protection for performers' right under the WIPO Performances and Phonograms Treaty 1996 (hereinafter the WPPT) in many aspects. This is because Thailand has not ratified the WPPT yet. However, the Rome Convention which is used as a model for the provisions in the Thai CA 1994 clearly provides lower standard of protection for performers' rights than that of the WPPT.

The provisions on the protection of performers' rights in Thailand

*Corresponding author: Dr. Noppanun Supasiripongchai, Director Intellectual Property Law Research and Development Center (IPLRDC), Faculty of Law, University of Phayao, Thailand, Tel: + 66 (0) 54466666; E-mail: noppanun.su@up.ac.th

Received May 14, 2014; Accepted September 17, 2014; Published September 25, 2014

Citation: Supasiripongchai N (2014) The Protection of Performer's Rights under the Copyright Law in Thailand: The Proposed Reform in the Light of the Prospective Free Trade Agreements with the United States and European Union. Intel Prop Rights 2: 127. doi:10.4172/2375-4516.1000127

Copyright: ( 2014 Supasiripongchai N. This is an open-access article distributed under the terms of the Creative Commons Attribution License, which permits unrestricted use, distribution, and reproduction in any medium, provided the original author and source are credited. 
need to be reformed in order to meet the standard of the protection for performers' rights under the WPPT for the following reasons. First, if Thailand is going to sign the Free Trade Agreements (FTA) with the United States (US) and the European Union (EU), it is likely that both FTA agreements would require Thailand to ratify the WPPT. In this aspect, a FTA is a trade treaty between two or more countries to establish a free trade area in which they agree to reduce or completely remove most or all tariffs, quotas, special fees and taxes, and other barriers to trade between the entities [4]. Recently, the US has FTAs in force with 20 countries, which are: Australia, Bahrain, Canada, Chile, Columbia, Costa Rica, Dominican Republic, El Salvador, Guatemala, Honduras, Israel, Jordan, Korea, Mexico, Morocco, Nicaragua, Oman, Panama, Peru and Singapore [5]. The Thai Government has already signed FTAs with several countries such as Australia, New Zealand, India, Japan, Peru and so on [6], but the FTA which Thailand is going to sign with the US seems to be different from any previous FTAs with other countries. This is because previous FTAs do not require Thailand to change its existing laws and regulations in order to accommodate the Agreement. For instance, under the Thailand-Japan FTA agreement and the Thailand-Australia FTA agreement, the Thai Government will not enact or modify laws, but will instead formulate some internal guidelines or set up procedures to accommodate investors and companies in order to comply with the FTA. This is different from the US FTA model which normally requires accession to several international copyright agreements and leads later to a new copyright law or amendment to copyright law of the trading partner [7]. For example, the US FTAs with Australia [8], Singapore [9], Bahrain [10], and Morocco [11] identically require the contracting countries to ratify or accede to the WPPT if they have not already done so. Currently, six rounds of the Thailand-US FTA negotiations have taken place. If the FTA agreement between Thailand and the US is reached, it is likely that this prospective FTA would require Thailand to ratify or accede to the WPPT and such accession would require increasing the level of the protection of performers' rights above that currently provided by the Thai CA 1994.

Similarly, the EU FTAs also requires that the protection of performers' rights granted by the contracting parties should be in compliance with the WPPT [12]. For example, Article 5.1(d) of the draft of the EU-ASEAN FTA and Article 10.5(d) of the EU-Korea FTA identically require the contracting parties to comply with Articles 1 through 23 of the WPPT 1996 [13]. The draft of the EU-ASEAN FTA is likely to be used as a model for Thailand and European FTA. In this aspect, the European Council adopted a mandate for the European Commission to start FTA negotiations with ASEAN countries which are Thailand, Myanmar, Brunei, Cambodia, Indonesia, Laos, Malaysia, Philippines, Singapore, and Vietnam. At first, the European Commission decided to go for a regional approach on the ASEAN negotiations for FTA and seven negotiations rounds were held with the ASEAN [14]. However, since the level of economic development of ASEAN countries is very different and some ASEAN countries are not ready to fully open their domestic market for the European goods and services as required under the EU FTA, so negotiations on FTA with ASEAN have not made much progress. Hence, the European commission decided to change its approach and announced that the EU will engage in the FTA negotiation with individual ASEAN countries such Singapore, Thailand, Vietnam and Malaysia, which have sufficient level of economic development and are ready to accept the conditions under the EU FTA [15]. However, although the EU has change its approach to negotiate with individual ASEAN countries including Thailand, the provisions on intellectual property in the EU
FTA for Thailand and other ASEAN countries would be identical to the draft of EU-ASEAN FTA. Hence, it is likely that the provision which requires the contracting parties to ratify the WPPT would be inserted into the Thailand-EU FTA. Thus, the issue of implementing the provisions on the protection of performers' rights in the WPPT is also the main concern before signing both US and EU FTAs because WPPT is not in force in Thailand and Thailand is not a party to the WPPT yet. This clearly shows that the demands of the EU and the US in their FTAs surpass all obligations of Thailand with respect to the other international Intellectual property agreements such as TRIPS Agreement.

Second, since Thailand has its obligation to implement the ASEAN Economic Community (AEC) in 2015, it is unavoidable to make its intellectual property laws including the laws on the protection of performers' rights consistent with other ASEAN countries in accordance with the ASEAN Intellectual Property Rights Action Plan (AIPRAP). This action plan is formulated in order to achieve the goal of harmonization of IP laws in ASEAN countries by encouraging the counties in ASEAN to become the membership of international IP treaties, including the WPPT [16]. This can be seen clearly in the AIPRAP for 2004-2010 which requires ASEAN countries to consider the issues and implications in accession and compliance with the WPPT [17].

It is likely that the standard of the protection for performers' rights under the WPPT will be used as a new standard of the protection of performers' rights in ASEAN countries because many ASEAN countries such as Indonesia, Malaysia, Philippines, and Singapore which is going to join the AEC in 2015 have already ratified the WPPT. Further, ASEAN will be developed into ASEAN+3 which is ASEAN countries plus China, Japan, and South Korea and then ASEAN+6 which is the ASEAN countries plus six countries such as China, India, Japan, South Korea, Australia and New Zealand in order to achieve the goal of establishing an ASEAN+6 Free Trade Agreement (FTA). It is likely that such agreement will also require the ratification and accession to the WPPT since many countries in ASEAN + 6 such as Japan China, Republic of Korea, Australia have already ratified the WPPT, so the standard of the protection of performers' rights under the WPPT will eventually become a new standard of the protection for performers' rights in both ASEAN countries and other six countries as well. Therefore, the reform of the provisions on the protection of performers' right in order to make them consistent with the standard under the WPPT seems to be unavoidable for Thailand. Nevertheless, by following the approach on the protection of performers' rights in the WPPT, it would benefit Thailand in preparing itself for the prospective FTAs with the EU and the US that require the contracting countries to ratify WPPT, while at the same time making the provisions on the protection of performers' rights under the Thai CA 1994 consistent with the law and system of some ASEAN countries which are already the signatory countries to the WPPT. This would also promote the harmonization of the IP laws in ASEAN.

This article will illustrate two important facts: 1) the provisions on the protection of performers' rights under the Thai CA 1994 as present do not meet the standard of the protection of performers' rights under the WPPT; 2) the provisions on the protection of performers' rights under the Thai CA 1994 are not consistent with the provisions in the prospective FTA of the US and that of the EU. Therefore, the objective of this article is to make the recommendation on how the provisions on the protection of performers' rights in the Thai CA 1994 should be developed or reformed in order to provide better protection for 
performers in Thailand, while at the same time ensuring that such provisions would be compatible with the WPPT and the prospective FTAs of the US and the EU.

This article points out the area of the protection of performers' rights that need to be reformed and changed in order to meet standard of protection under the WPPT and the prospective FTAs of the US and the EU. It will divide the discussion into the following sections: 1) the definition of performers; 2) the exclusive rights of performers; 3) the right to remuneration of the performer; 4) moral rights of performers; 5) term of protection for performers' rights; 6) exception to an infringement of performers' rights; 7) the protection of the Technological Protection Measures (TPM) for performers; 8) the protection of the Right Management Information (RMI) of performers.

\section{Definition of Performers}

Pursuant to paragraph 11 of section 4 of the CA 1994, performer means a performer, musician, vocalist, choreographer, dancer, and a person who acts, sings, speaks, narrates or performs in accordance with the script or performs in any other manner [18]. In the legislature process, the legislators decided to cut the term 'for literary or artistic work' from paragraph 11 of section 4 because it did not want the protection of performers' rights limited to only literary or artistic works [19]. This provision is based on Article 3(a) and 9 of the Rome Convention which guarantees that the protection of performers' rights is not limited to performers that perform literary or artistic works [20]. Nevertheless, if Thailand is going to ratify the WPPT, the scope of the term 'performers' under the CA 1994 which follows the standard under Article 3 (a) and Article 9 of the Rome convention, is not enough. This is because the scope of the term 'performers' under the Rome Convention is narrower than that under Article 2(a) of the WPPT, which provides that 'performers are actors, singers, musicians, dancers, and other persons who act, sing, deliver, declaim, play in, interpret, or otherwise perform literary or artistic works or expressions of folklore' [21]. According to the WIPO Diplomatic Conference on Audiovisual Performances 2000:

'The definition used in the WPPT differs from that of the Rome Convention only in two respects: it adds the term "interpret' to the list of types of performances, and it adds "expressions of folklore" to the scope of performances' [22].

Arnold believed that the WPPT strengthens the protection of performers' rights in international level by extending the definition of performers to include performers of folklore [23]. Since the definition of 'performers' under the Thai CA 1994 follows the approach in the Rome Convention, it does not include 'the performers of folklore' and this is clearly different from the definition of performers in the WPPT. Also, most US FTAs seem to take the similar approach as the WPPT by adding the term 'expressions of folklore' into the definition of performers in order to extend the scope of protection for performers' rights. For example, Article 16.5(4)(a) of the Singapore-US FTA and Article 17.6(5)(d) of the Australia-US FTA identically defines performers as 'actors, singers, musicians, dancers, and other persons who act, sing, deliver, declaim, play in, interpret, or otherwise perform literary or artistic works or expressions of folklore' [24]. In contrast, although the EU FTAs does not mention or contain the definition of performers, the contracting countries to the EU FTAs still need to follow the approach on the definition of performers in the WPPT by extending the scope of definition of performers to cover 'expressions of folklore' since most EU FTAs also require the contracting parties to ratify the WPPT. Thus, this article recommends that the scope of the term 'performers' in the Thai CA 1994 should be extended to cover 'expressions of folklore' in order to make it compatible with the standard of the protection of performers' rights under the WPPT and the prospective FTAs of the US and EU. This would also promote the harmonization of the protection of performers' rights in the region of South East Asia because the scope of protection under the definition of performers in the Thai CA 1994 will be the same as some ASEAN countries which have already ratified the WPPT.

\section{The Exclusive Rights of Performers}

Under the Thai CA 1994, performers have two types of economic rights, which are the exclusive rights and the rights to remuneration for broadcasting and communication to the public. Both rights can be assigned to others whether in whole or in part for the entire term of protection [25]. This section only considers the issue relating the exclusive rights of performers, while the issue relating to the rights to remuneration of performers will be considered in the next section. Currently, the protection of performers' exclusive rights under the Thai CA 1994 does not meet the standard under the WPPT because the WPPT provides wide range of exclusive rights for performers and some of these rights do not appear in the Thai CA 1994 and the Rome Convention [26]. Thus, if Thailand is going to ratify the WPPT, some provisions of the CA 1994 must be reformed in order to make them compatible with the WPPT and also some new exclusive rights of performers contained in the WPPT need to be inserted into the CA 1994 such as exclusive rights of distribution in Article 8, right of rental in Article 9, right of making the fixed performances available to the public in Article 10 of the WPPT.

Pursuant to section 44 of the CA 1994, performers have the exclusive rights with respect of the acts concerning their performances of:

'(1) sound and video broadcasting or communication to public of the performance except the sound and video broadcasting or communication to public from a recording material which has been recorded;

(2) Recording the performance which has not been recorded;

(3) Reproducing the recording material of the performance which has been recorded without the consent of the performer or the recording material of the performance with the consent of the performer but for another purpose or the recording material of the performance which falls within the exceptions of the infringement of performer's rights' [27].

This provision is intended to protect only live performance or unfixed performances [28]. Although it does not use the phrase 'live performance', it excludes sound and video broadcasting or communication to the public from a recording material which has been recorded from protection in subsection (1) as well as emphasizing that the performers have exclusive right on the recording the performance which has not been recorded in subsection (2). The coverage of the exclusive rights of performers under section 44(1) of the CA 1994 is similar to that under the TRIPS Agreement [29], but one difference is that section 44(1) extends to all kinds of live performances including the live aural performances. This seems to be consistent with the right of broadcasting and communication to the public of live performances in Article 6(i) of the WPPT, which extends to cover all kinds of live performances including aural performance by provides that performers shall enjoy the exclusive right of authorizing the broadcasting and 
communication to the public of their unfixed performances except where the performance is already a broadcast performance [30].

It is important to note that the scope of the right of authorizing the broadcasting and the right of communication to the public of unfixed performances contained in Article 6(i) of the WPPT seems to be different. In this instance, the broadcasting right includes aural performances and also audiovisual performances since the definition of broadcasting in Article 2(f) of WPPT includes 'sounds' and 'sounds and images' [31], while right of communication to the public only covers aural performances because the definition of communication to the public in Article 2(g) of WPPT only extends to 'sounds' or 'representations of sounds' [32]. This difference between scope of the broadcasting right and right of communication to the public not only applies in case of unfixed performances in Article 6(i), but also applies to the right to remuneration for broadcasting and communication to the public relating to fixed performances in Article 15 of the WPPT. In this instance, the right to remuneration for broadcasting of fixed performances in Article 15 of the WPPT can cover both aural performances and audiovisual performances, but the right to remuneration for communication to the public of fixed performances seems to limit its application to fixations of sounds and representations of sounds, not extending to audiovisual performances [33]. This issue will be discussed in more details in the next section.

Similar provision which provides protection for the right of authorizing the broadcasting and right of communication to the public of unfixed performances also appears in the US FTAs. For instance, the Singapore-US FTA and the Chile-US FTA identically require that the contracting parties must provide the performers the right to authorize or prohibit the broadcasting and communication to the public of their unfixed performances except where the performance is already a broadcast performance [34]. Likewise, the draft of the EU-ASEAN FTA and the EU-the Republic of Korea FTA also require contracting parties to provide to the performers the exclusive right to authorize or prohibit the broadcasting by wireless means and the communication to the public of their performances, except where the performance is itself already a broadcast performance or is made from a fixation [35].

These provisions have one thing in common that they all exclude a rebroadcast or wired retransmission of a broadcast of an unfixed performance from the scope of the protection. This is different from section 44(1) of the Thai CA 1994, which only excludes the sound and video broadcasting or communication to public from a recording material which has been recorded from the protection, but there is no exception as to where the performance used in the broadcasting or public communication is itself already a broadcast performance in section 44(1). This makes section 44(1) different from Article 6(1) of the WPPT which does not allow the exclusive right of authorizing the broadcasting and communication to the public to apply where the performance is already a broadcast performance. Since section 44(1) already prevents the exclusive right of authorizing the broadcasting and communication to the public from applying where the performance used in the broadcasting or public communication is made from a fixation or a recording material, this article recommends that Thailand should add one exception or condition into section 44(1) that such provision does not apply where the performance is already a broadcast performance. In other words, Thailand should follow the approach in the EU FTAs, which explicitly prevents the exclusive right of authorizing the broadcasting and communication to the public from applying where the performance is already a broadcast performance or is made from a fixation or a recording material.
Section 44(2) provides that the performer has the exclusive right on the recording the performance which has not been recorded in subsection (2). This provision is also intended to protect only live performance [36], while at the same time providing the performers with the right to authorize or prevent the recording of their live performance. This seems to be consistent with Article 6(ii) of the WPPT, which provides that performers shall enjoy the exclusive right of authorizing the certain acts relating to their performances, namely: the fixation of their unfixed performances [37]. Under this provision, the performers have the right to authorize or prevent the recording of their live performance or the fixation of their unfixed performance as well as preventing the reproduction of the fixation of their live performance. Likewise, the US FTAs such as Singapore-US FTA and the Chile-US FTA also require the contracting parties to provide to the performers the right to authorize or prohibit the fixation of their unfixed performances [38]. In contrast, unlike the US FTAs, the similar provision to that of Article 6(ii) of the WPPT does not appear in the EU FTAs, but the contracting parties of the EU FTAs still need to insert such provision into its national law since the EU FTAs also requires the contracting parties to ratify the WPPT.

However, it is important to note that the application of Article 6(ii) raises the question of whether the right to authorize fixation of unfixed performances in Article 6(ii) extends to all fixations or only to fixations on phonograms [39]. If the definition of "fixation" under Article 2(c) is taken into account, it seems that a narrower interpretation is justified [40]. Pursuant to the definition of "fixation" in Article 2(c) of the WPPT, "fixation" means 'the embodiment of sounds, or of the representations thereof, from which they can be perceived, reproduced or communicated through a device' [41], so Article 6(ii) seems to only extend to fixation on phonograms [42]. The similar definition of the term "fixation" also appears in both the US FTA and the EU FTA. For instance, the provisions in the Singapore-US FTA and the EU-ASEAN FTA identically defines the "fixation" as "the embodiment of sounds, or of the representations thereof, from which they can be perceived, reproduced, or communicated through a device' [43]. As a result, the scope of the application of the right to authorize fixation of unfixed performances in these FTAs is the same as that of Article 6(ii), which can be interpreted to limit the application of such right to a live performances fixed on phonogram and to the reproduction of this recording. This is different from section 44 (2) of the Thai CA 1994 which does not use the term "fixation", but uses the term "recording" instead and such term is not defined in the Thai CA 1994, so it is unclear whether the right to authorize or prevent the recording of their live performance or the fixation of unfixed performances in section 44(2) of the CA 1994 extends to all fixations or only to fixations on phonograms.

This article recommends that Thailand should follow the approach of the WPPT, the EU FTA and the US FTA by defining the term "recording" or replacing the term "recording" with the term "fixation" together with the insertion of the clear definition of the term "fixation" - either way it is necessary to ensure that the definition of such term must carry the same meaning and scope as those in the WPPT, the EU FTA and the US FTA. Without insertion of such definition, the current provision could be interpreted to apply to all fixations or all recording of the performance which has not been recorded and as a result, this would increase the burden of the enforcement of such provision for Thailand. In this instance, the insertion of the definition with the same scope as those in the WPPT, the EU FTA and the US FTA would ensure that the scope of the application of section 44(2) is limited to only the fixations on phonograms and does not extend 
to all fixations on other sources and therefore, helps to narrow down the scope of the application of this provision and make it more certain and easier to enforce in practice. It is undeniable that narrower scope of the provision means less problems and easier enforcement. Thus, this proposed change does not only make section 44(2) of the CA 1994 consistent with the provisions in the WPPT, the US FTA and the EU FTA, but also helps to reduce the burden of the enforcement of such provision for Thailand.

The exclusive right of reproduction contained in section 44(3) of the CA 1994, which provides to the performers the rights of: the reproduction of the recording material of the performance which has been recorded without the consent of the performer; the reproduction of the recording material of the performance with the consent of the performer but for another purpose; and the reproduction of the recording material of the performance which falls within the exceptions to the infringement of performers' rights. In general, the provision in section 44(3) seems to be better than the protection of the reproduction right of performers under Article 14(1) of the TRIPs Agreement because section 44(3) is based on Article 7(1) (c) of Rome Convention, which provides better protection than that of Article 14(1). In this aspect, the exclusive right to reproduction of performers under Article 14(1) of the TRIPs Agreement is limited to a fixation of performance on a phonogram only and does not provide protection for the reproduction rights of performer in the fixation of performance on other sources, but such limitation does not appear in that of Article 7(1) (c) of the Rome Convention and section [44] (3) of the Thai CA 1994 [45].

However, the scope of the reproduction right of performers in section 44(3) is still not broad enough to meet the standard of the reproduction right under Article 7 of WPPT, which provides that performers shall enjoy the exclusive right of authorizing the direct or indirect reproduction of their performances fixed in phonograms in any manner or form [46]. In this instance, the reproduction right in Article 7 of the WPPT extends to "direct or indirect reproduction". The origin of the phrase "direct or indirect reproduction" comes from Article 10 of the Rome Convention, but this Article concerns only the rights of producers of phonograms, which is different from Article 7 of the WPPT that focuses on the right of reproduction for both performers and producers of phonograms [47]. Although the term "direct or indirect reproduction" is not defined in the WPPT [48], it is understood that the term "direct reproduction" includes a reproduction by use of a record press and other similar means, while the term "indirect reproduction" can cover a reproduction by recording a radio or TV program which contains a phonogram [49]. Hence, the use of term "direct or indirect reproduction" together with the use of an inclusive term such as reproduction "in any manner of form" allow the provision of Article 7 of the WPPT to cover all types of reproductions of the performances [50]. In contrast, section 44(3) of the Thai CA 1994 does not contain the equivalent terms to Article 7 of the WPPT, so it is unclear whether the scope of the provision in section 44(3) can cover indirect reproduction. In other words, the reproduction by recording a radio or TV program which contains a phonogram might not fall within the scope of section 44(3). Also, with no equivalent term as to the phrase reproduction "in any manner of form", the application of the reproduction right under section 44(3) of the CA 1994 is still limited, so section 44(3) of the CA 1994 need to be reformed by inserting the term "direct or indirect reproduction" together with the inclusive term such as reproduction "in any manner of form" into section 44(3) in order to guarantee that the performers would have the exclusive right to authorize both direct or indirect reproduction of their performances in any manner of form in accordance with Article 7 of WPPT.
Significantly, it is important to note that the protection of reproduction right of performers under the Thai CA 1994 and the Rome convention are less effective in the digital environment. This is quite different from Article 7 of the WPPT, which can fully apply in the digital environment. The WIPO indicated that Articles 7 can apply in the digital environment and in particular to the use of performances and phonograms in digital form [51]. Further, it formulated a set of rules aim at strengthening the rights of performers in their audiovisual performances, which is known as the provisional agreement on Audiovisual Performances [52]. In this vein, the right to reproduction under Article 7 is limited to performances fixed in phonograms, and does not cover the rights of performers in the audiovisual fixations of their performance [53], so the provisional agreement on audiovisual performance is quite important in fulfilling the gap of the WPPT in protecting audiovisual performance. One of the concerns of the WIPO provisional agreement is:

'Recognizing the great importance of ensuring an adequate level of protection for these performances, in particular when they are exploited in the new digital environment, and that sound and audiovisual performances are increasingly related'[54].

The WIPO states that the provisional agreement on audiovisual performances strongly linked to the WPPT and built on references to its provisions [55]. It strengthens the protection of performers' rights including the reproduction rights in audiovisual performance and provides an adequate level of protection for the performance in the digital environment. It is likely the ratification of the WPPT and its provisional agreements would lead to many changes in the Thai CA 1994 which would make the protection of performers' rights especially the reproduction rights more adaptable to the digital environment.

It is important to mention the reproduction right of performers in the provision of the US FTAs because it contains specific approach which does not appear in the provision of the WPPT. In this vein, the provisions in the US FTAs extend the scope of the reproduction right of performers to cover all reproductions in any manner or form, which includes both permanent and temporary reproduction. For example, the Singapore-US FTA and the Chile-US FTA identically requires the contracting parties to provide to performers the right to authorize or prohibit all reproductions of their performances or phonograms, in any manner or form, permanent or temporary including temporary storage in electronic form [56]. In contrast, the definition of the term "reproduction" in section 4 of the CA 1994 does not mention about temporary reproduction and thus, it is unclear whether temporary reproduction, including reproductions of the performances temporary storage in electronic form will be part of the reproduction right of the performers under the CA 1994. If Thailand is going to sign the FTA with the US, it needs to ensure that the scope of the reproduction right of performer under the CA 1994 can cover all reproductions in any manner or form, including temporary reproduction. The reform should be made to the definition of the term "reproduction" in section 4 of the CA 1994 in order to extend the scope of the term "reproduction" to include temporary reproduction or reproductions of the performances temporary storage in electronic form.

In contrast, although the provision relating to the temporary reproduction does not appear in the EU FTAs, it is likely that such provision would be accepted by the European countries since the similar approach, which allows the reproduction right of performer to cover temporary reproduction also appears in Article 2(b) of the EU Copyright Directive [57]. This provision requires the member States to provide to the performers the exclusive right to authorize or prohibit 
direct or indirect, temporary or permanent reproduction by any means and in any form, in whole or in part of fixations of their performances [58]. However, this Directive also recognized the importance of having the exception allowing certain act of temporary reproduction in the preamble (33), which indicates:

'The exclusive right of reproduction should be subject to an exception to allow certain acts of temporary reproduction, which are transient or incidental reproductions, forming an integral and essential part of a technological process and carried out for the sole purpose of enabling either efficient transmission in a network between third parties by an intermediary, or a lawful use of a work or other subject-matter to be made. The acts of reproduction concerned should have no separate economic value on their own. To the extent that they meet these conditions, this exception should include acts which enable browsing as well as acts of caching to take place, including those which enable transmission systems to function efficiently, provided that the intermediary does not modify the information and does not interfere with the lawful use of technology, widely recognized and used by industry, to obtain data on the use of the information. A use should be considered lawful where it is authorized by the right holder or not restricted by law' [59].

It is undeniable that without the exceptions allowing certain acts of temporary reproduction, the exercise of reproduction right in respect of temporary reproduction may affect the operation or the function of new digital technologies. For instance, most digital files that are opened on the computer have reproductions made of them in RAM (temporary storage in electronic form). Also, the temporary reproduction might often be essential part of a technological process in order to enable efficient transmission in a network as well as enabling browsing or acts of caching to take place on the Internet. Hence, this article recommends that if Thailand is going to extend the scope of the reproduction right to cover the temporary reproduction, it is necessary for Thailand to provide the exception to allow certain acts of temporary reproduction in order to ensure that the reproduction right of performers would not affect the function or operation of the new digital technologies.

Under the US FTAs, the exceptions relating to the temporary reproduction can still be inserted into the national law of the contracting countries, but such exception must be subject to the three-step test. For instance, the Singapore-US FTA and the Australia-US FTA allow the contracting parties to provide the exception to the exclusive right of performers by stipulating that contracting parties must confine limitations or exceptions to exclusive rights to certain special cases which do not conflict with a normal exploitation of the performance, or phonogram, and do not unreasonably prejudice the legitimate interests of the right holder [60]. Hence, Thailand can regulate the exceptions to allow certain acts of temporary reproduction to be done in accordance to the three-step test. In this aspect, the three-step test, which appears in the US FTA, comes from Article 9 of the Berne Convention and Article 13 of the TRIPs Agreement. The issue relating to the exceptions and the three-step test will be discussed in more details in section 7 .

As already noted, if Thailand is going to ratify the WPPT, some new exclusive rights of performers such as the right of distribution in Article 8, right of rental in Article 9, the right of making the fixed performances available to the public in Article 10 of the WPPT would need to be inserted into the Thai CA 1994 since the current CA 1994 does not provide or mention about the protection of these rights of performers. First, the exclusive right of distribution in Article 8 of WPPT, which provides that performers shall enjoy the exclusive right of authorizing the making available to the public of the original and copies of their performances fixed in phonograms through sale or other transfer of ownership [61]. This distribution right extends to the sale or other transfer of ownership of the original and copies of fixed performances [62]. The similar provision also appears in the US FTAs. For instance, the Singapore-US FTA and the Chile-US FTA identically require the contracting parties to provide to performers and their successors the exclusive right of authorizing the making available to the public of the original and copies of their performances or phonograms through sale or other transfer of ownership [63]. Although the EU FTAs do not specifically mention this right, the contracting parties to the EU FTAs still have to insert this provision when they ratify the WPPT since such accession to the WPPT is normally required by all EU FTAs.

Nevertheless, it is important to note that the right of distribution in Article 8(1) of the WPPT is still subject to the principle of exhaustion in Article 8(2) of the WPPT. Pursuant to Article 8(2), the contracting parties have the freedom to determine the conditions in case where the exhaustion of the distribution right of performer in Article 8(1) applies after the first sale or other transfer of ownership of the original or a copy of the fixed performance with the authorization of the performer [64]. In other words, if the distribution right of performer can be exhausted, then the contracting parties are free to determine the conditions for exhaustion and this means that they can choose the model of exhaustion such as national exhaustion, regional exhaustion or international exhaustion to apply in their national law [65]. Thus, the application of this article is quite flexible, and this allows Thailand to choose whether it would apply the principle of exhaustion to the distribution right of performers and if it chooses to apply such principle, it still retains the freedom to choose the legal model of exhaustion to apply in the context of performers' rights.

The second exclusive right which needs to be inserted into the Thai CA 1994 is the rental rights in Article 9 of WPPT. In this aspect, the CA 1994 does not provide rental rights for performers, which is the same as the Rome Convention. This is different from the WPPT, which clearly requires the contracting countries to provide the protection for rental rights of performers in their national law by stating that performers should enjoy the exclusive right of authorizing the commercial rental to the public of the original and copies of their performances fixed in phonograms even after distribution of them pursuant to the authorization by the performer [66]. Nevertheless, the obligation under Article 9(1) does not require a contracting party to provide the exclusive right of commercial rental to performers who are not granted rights under national law of the contracting party [67]. Further, it stipulates in Article 9(2) that contracting countries, which have in force a system of equitable remuneration of performers for the rental of copies of their performances fixed in phonograms, may maintain such system provided that the commercial rental of phonograms is not giving rise to the material impairment of the exclusive right of reproduction of performers [68]. In contrast, the CA 1994 contains no provision equivalent to Article 9(2) of the WPPT. Presently, Thailand does not have a system of equitable remuneration of performers for the rental of copies of their performances fixed in phonogram. Indeed, Thailand would need to comply with Article 9(2) of the WPPT only if it wants to establish the system of equitable remuneration for performers. In such case, Thailand would need to insert such provision into the Thai CA 1994 in order to comply with Article 9(2) of the WPPT. Nonetheless, if Thailand has no plan to establish the system of equitable remuneration for performers, then it does not need to comply with Article 9(2), but only needs to insert Article 9(1) into the CA 1994 in order to guarantee the exclusive right of authorizing the commercial rental for performers. Importantly, even though the rental right of 
performers is not directly mentioned in both the US FTAs and the EU FTAs, the contracting parties to the US FTAs and the EU FTAs still have to provide the protection for this rental right in their national law since both the US FTA and EU FTA require the contracting countries to ratify the WPPT. Hence, if Thailand is going to sign the FTAs with the EU and the US, it needs to provide the protection for rental right of performer in accordance with Article 9 of the WPPT.

Another exclusive right of performer in the WPPT which need to be inserted into the Thai CA 1994 is the right of making the fixed performances available to the public. Pursuant to Article 10 of WPPT, the contracting parties must provide the performers the exclusive right of authorizing the making available to the public of their performances fixed in phonograms by wire or wireless means in a way that the members of the public can access them from a place and at a time individually chosen [69]. The right of making the fixed performances available to the public is the on-demand availability right because it focuses on the requirement that individuals must be able to access such materials from a place and at the time they choose [70]. Nevertheless, the right of making the fixed performances available to the public in Article 10 of WPPT is limited to availability of performances fixed in phonograms, and does not cover performances in audiovisual fixations, which is the same as Article 7 of the WPPT [71]. The similar provision also appears in the US FTAs such as the Singapore-US FTA and the Chile-US FTA which require the contracting parties to provide to the performers and their successors the exclusive right to authorize or prohibit any communication to the public of their performances or phonograms, by wire or wireless means, including the making available to the public of their performances and phonograms in such a way that members of the public may access them from a place and at a time individually chosen by them [72]. Although the right of making the fixed performances available to the public of performers is not specifically mentioned in the EU FTAs, the contracting parties to the EU FTAs still have to provide the protection for this right in their national law because all EU FTAs require the ratification of the WPPT which guarantees the protection of this right in Article 10.

\section{The Right to Remuneration for Broadcasting and Communication to the Public}

As already mentioned in the previous section, the CA 1994 recognizes two types of economic rights of performers, which are the exclusive rights of performers and the right to remuneration for broadcasting and communication to the public. The right to remuneration can also be assigned to others whether in whole or in part for the whole term of protection and is recognized in section 45 of the Thai CA 1994. Pursuant to section 45 of the Thai CA 1994, a person who directly uses a sound recording of a performance or the copies of it must pay an equitable remuneration to the performer if the two conditions are met [73]. First, a sound recording of a performance must have been published for commercial purposes and second, that sound recording of a performance or the copies of it must be directly used in a broadcast or a communication to public [74]. If a user of performances and the performers cannot agree on the rate of remuneration, section 45 provides the Director General of the Department of Intellectual Property (DIP) with the authority to stipulate the remuneration by taking into account the normal rate of remuneration in such specific business [75]. Nevertheless, if the parties do not agree with the order of the Director General, they may appeal against the order of the Director General to the Copyright Committee within ninety days from the date of the receipt of the letter informing the order of the Director General and the decision of the the Copyright Committee must be final
[76]. In case where there are more than one performer involved in a performance or an audio recording of a performance, section 46 allows these performers to appoint a joint agent to take care of their right or administer their rights [77].

The rights to remuneration of performers in section 45 are based on Article 12 of the Rome Convention [78]. However, there is one difference between these two provisions that is Article 12 protects the rights of performers and the producers of the phonograms, but section 45 of the Thai CA 1994 only protects performers' rights. This is because the producers of phonograms are protected as the copyright owners under the Thai CA 1994 since phonograms can be regarded as copyright works under this Act. Hence, the producers of phonograms can claim protection for their phonograms as the owners of copyright works, which is better than the protection for the owner of performers' rights because the Thai CA 1994 grants wider and better protection for copyright than performers' rights. For instance, the CA 1994 provides the copyright owners the exclusive right to make or authorize adaptation or modification in respect of their works, while it does not provide such right to performers in respect of their fixed performance. Also, the CA 1994 provides the protection for moral right of author in section 18 , but such provision does not extend its protection to cover moral right of performers even if such the adaptation or modification of the fixed performance could potentially undermine the reputation of performers. In other words, such adaptation or modification of the fixed performance without prior authorization from performers may not result in an infringement of both exclusive right of performers under section 44 and moral right in section 18 of the Thai CA 1994. The issue relating to the right of adaptation and moral right of performers will be discussed in more details in section 5 and section 9 .

It is important to note that the protection for the rights to remuneration of performers under section 45 of the Thai CA 1994 and Article 12 of the Rome Convention is better than that of the TRIPs Agreement because although the TRIPs Agreement provides the protection for the rights to remuneration of performers, but such protection does not apply where the phonograms have been directly used for broadcasting or for any communication to the public. Nevertheless, both section 45 and Article 12 still falls short of the standard protection under the WPPT because they are only limited to the direct use of phonogram for broadcasting or communicating to the public. This is different from Article 15(1) of the WPPT which stipulates that performers and producers of phonograms shall enjoy the right to a single equitable remuneration for the direct or indirect use of phonograms published for commercial purposes for broadcasting or for any communication to the public [79]. Thus, the protection of the rights to remuneration of performers under the WPPT is not limited to the direct use of phonogram since it extends to cover both the direct and indirect use of phonograms for broadcasting or communicating to the public. Nevertheless, Thailand may not need to implement the provision in Article 15(1) immediately after it ratifies the WPPT because Article 15(3) allows the contracting parties to make or declare the reservation regarding Article 15(1) in a notification deposited with the Director General of WIPO in three different ways [80]. First, the contracting party could apply the provisions of Article 15(1) only in respect of certain uses [81]. For instance, it may apply the right to remuneration to the case of broadcasting only, but not to case of communication to the public [82]. Second, the contracting party could limit the application of the provision in Article 15(1) in some other way [83]. For instance, it may exclude either performers or producers of phonograms from the scope of the rights to remuneration or from 
coverage of beneficiaries of such rights [84]. Third, the contracting party may not apply the provision in Article 15(1) at all [85].

Nonetheless, it is important to note that the possibility of declaring the reservations in a notification deposited with the Director General of WIPO only applies to Article 15(1), but not to Article 15(2) [86]. Hence, Thailand needs to add or insert Article 15(2) into the provisions on the protection of performers' rights under the Thai CA 1994. In this vein, Article 15(2) of WPPT requires the contracting parties to establish in their national legislation that the single equitable remuneration shall be claimed from the user by the performer or by the producer of a phonogram or by both [87]. In the absence of an agreement between the performer and the producer of a phonogram, this Article requires the contracting parties to enact national legislation that sets the terms according to which performers and producers of phonograms must share the single equitable remuneration [88]. Similar approach also appears in the EU FTAs such as EU-Korea FTA and the draft of the EU-ASEAN FTA, which requires contracting parties to provide the performers the right in order to ensure that a single equitable remuneration is paid by the user, if a phonogram published for commercial purposes, or a reproduction of such phonogram, is used for broadcasting by wireless means or for any communication to the public [89]. Further, these EU FTAs also follow the approach in Article 15(2) of the WPPT by requiring the contracting parties to establish in their legislation that the single equitable remuneration must be claimed from the user by performers or producers of phonograms, or by both [90]. In the absence of an agreement between performers and producers of phonograms, the EU-Korea FTA and the draft of the EU-ASEAN FTA also requires the contracting parties to enact legislation that sets the terms or lays down the conditions in order to ensure that the single equitable remuneration is shared between the relevant performers and the producers of phonograms [91]. This is different from the US FTAs which do not specifically mention about these above provisions, but the contracting parties to the US FTAs still need to follow the approach of the WPPT in the same way as the contracting parties to the EU FTAs since most US FTAs also require the ratification of the WPPT which would eventually lead to the implementation these provisions of the WPPT in the end.

\section{Moral Right of Performers}

Moral right is different from the exclusive rights that focus on economic interests of the performers, because moral right aims to protect the dignity or reputation of the performers even after the transfer of those rights. Moral right of performers generally consists of the right of attribution and the right of integrity. First, a moral right of attribution is the right to be identified as performers of their performances. This right is sometime referred to as the right of paternity. The right of attribution enables the performers to claim to be identified as the performers of their performances and thus, obliges others to communicate these performances under their name. With this right, the performers can demand the licensees, assignees or others to acknowledge them as the performers whenever their performance made known to the public. Second, a moral right of integrity is the right of performers to object to any distortion, mutilation or other modification of their performances, which affects the reputation of performers [92]. This right entitles performers to oppose any alteration or distortion of their performances that prejudices their reputation. With this right, the performers can require others to stop such adaptation, distortion or any acts detrimental to his honour or reputation. Both moral rights of attribution and integrity are also embodied recognized under Article $5(1)$ of the WPPT, which provides:
'Independently of a performer's economic rights, and even after the transfer of those rights, the performer shall, as regards his live aural performances or performances fixed in phonograms, have the right to claim to be identified as the performer of his performances, except where omission is dictated by the manner of the use of the performance, and to object to any distortion, mutilation or other modification of his performances that would be prejudicial to his reputation' [93].

These moral rights could be maintained after the death of performer for at least until the expiry of the economic rights and should be exercisable by the persons or institutions authorized by the legislation of the contracting country where protection is claimed [94]. Hence, the WPPT clearly strengthens the protection of performers' rights by granting performers moral right as well as protecting such right even after the death of performers and this makes it better than the Rome Convention and the TRIPs Agreement [95].

Currently, the Thai CA 1994 provides the protection of moral rights of integrity and attribution to only the author of copyright works in section 18 of the CA 1994. First, section 18 recognizes the right of attribution by providing that the author of a copyright work is entitled to identify himself as the author of such copyright works even after the transfer of his exclusive rights in that work to another [96]. Second, this section recognizes the right of integrity by indicating that the author of a copyright work can prohibit the assignee or any other person from distorting, shortening, adapting or doing anything with the work to the extent that such act would cause damage to the reputation or dignity of the author [97]. This section also protects the moral rights after the death of the author by providing that the heir of the author is entitled to enforce moral rights through the entire term of copyright protection.

Nevertheless, section 18 of the CA 1994 does not extend its protection to cover the moral rights of performers. This is the same as the TRIPs Agreement and the Rome Convention, which contain no provision on the protection of moral rights of performers. Likewise, the provision on the protection of moral rights of performers does not appear in the US FTAs and the EU FTAs, but the contracting parties to these FTAs of the EU and the US would still have to insert and implement the provision on the protection of moral rights of performers in Article 5(1) of the WPPT into their national copyright laws since these FTAs identically require the contracting parties to ratify the WPPT. Hence, if Thailand is going to sign the FTAs with the US or the EU, then it would have to provide the protection for moral right of performers in accordance with Article 5(1) of the WPPT.

\section{The Term of Protection for Performers' Rights}

The term of the protection for the exclusive rights of performers is regulated in section 49 of the CA 1994, which provides that term of protection for the exclusive rights of performers shall last for fifty years from the last day of the calendar year in which the performance takes place or if the performance is recorded, term of protection shall last for fifty years from the last day of the calendar year in which the recording of the performance takes place [98]. Similarly, section 50 of the CA 1994 provides that the term of protection for the rights to remuneration of performers shall last for fifty years from the last day of the calendar year in which the audio recording of the performance takes place [99]. The term of protection for these rights of performers under CA 1994 is longer than the standard term of protection under Article 14 of the Rome Convention, which provides the term of protection for only twenty years from the end of the year in which the fixation was made or the performance took place [100]. This is because the term of protection in both section 49 and 50 is based on the term of protection 
under Article 14(5) of the TRIPS Agreement, which provides that the term of the protection for performers' rights shall last at least until the end of a period of 50 years computed from the end of the calendar year in which the fixation was made or the performance took place [101]. Nevertheless, the term of protection under both sections 49 and 50 of the CA 1994 seems to be compatible with the standard term under Article 17(1) of the WPPT, which provides the term of protection for fifty years from the end of the year in which the performance was fixed in a phonogram. This means that Thailand does not need to make a change to the term of protection for performers' right in the CA 1994 if it ratifies the WPPT.

Nonetheless, the contracting countries to these international treaties are free to provide longer term of protection for performers' rights because the term of protection can be different in each country, but most of them seem to choose fifty years term of protection for performers' rights. For example, the European countries follow the approach in the European Copyright Directive which sets the term of protection for related rights including performers' rights at fifty years after lawful publication or communication to the public [102]. This is similar to the draft of the EU-ASEAN FTA which indicates that the term of protection for the rights of performers must be not less than 50 years after the date of the performance [103]. However, if a fixation of the performance is lawfully published or lawfully communicated to the public within this period, the term of protection for the rights of performer shall last for 50 years from the date of the first publication or the first communication to the public [104]. This is the same term of protection as that of the TRIPs Agreement and the CA 1994. Interestingly, it is important to note that although the term of protection for performers' rights in the Thai CA 1994 is the same term of protection as that in the EU Copyright Directive, the term of protection for copyright is different. The term of protection for copyrights under the CA 1994 provides for only fifty years after the death of the author and this is shorter than the term of protection under the EU Directive and the US Copyright Act which provides the term of copyright protection for seventy years.

Importantly, the term of protection for performers' rights under the US FTA seems to be different since the provisions in the US FTAs provide longer term of protection for performers' rights than those in the WPPT, the EU FTAs, EU Copyright Directive, the TRIPs Agreement and the CA 1994. For example, the term of the protection for performers' rights in the provisions of the SingaporeUS FTA, Chile-US FTA and Australia-US FTA seem to be identical since they stipulates that if the term of protection of performance is to be calculated on the basis of the life of a natural person, then the term shall be not less than the life of the performer and 70 years after the performer's death [105]. However, if the term of protection of a performance is to be calculated on a basis other than the life of a natural person, then the term must be not less than 70 years from the end of the calendar year of the first authorized publication of the performance [106]. In case failing such authorized publication within 50 years from the creation of the performance or phonogram, the term must be not less than 70 years from the end of the calendar year of the creation of the performance or phonogram [107]. This is longer than the term of protection under the Thai CA 1994, the WPPT, the EU FTAs and the TRIPs Agreement, which provides the term of the protection of performers' rights for a period of 50 years only [108]. Thus, signing the FTA with the US means that Thailand would have to extend the term of protection for performers' rights under its copyright law to be not less than 70 years in order to comply with the provision in the prospective Thailand-US FTA.

\section{Exceptions to an Infringement of Performers' Rights}

Pursuant to section 52 of the Thai CA 1994, any person who acts against the exclusive rights of the performers as specified in section 44 without consent of the performer or without paying remuneration in accordance with section 45 shall be deemed to infringe the performers' rights [109]. However, section 52 is subject to the exception under section 53, which stipulates that 'section 32 , section 33 , section 34 , section 36 , section 42 , and section 43 shall apply mutatis mutandis to performer's rights' [110]. These six sections which are mentioned in section 53 are the provisions of copyright exceptions. This means that the provisions on the protection of performers' right in the CA 1994 contain no exceptions of their own, but they rely on the copyright exceptions under the CA 1994. Therefore, these six sections, which provide exceptions to an infringement of copyright, must be applied mutatis mutandis as the exceptions to an infringement of performers' rights as well. This approach seems to be consistent with Article 15(2) of the Rome Convention, Article 14(6) of the TRIPS Agreement, and Article 16(1) of the WPPT, which provides that the contracting countries can regulate the exceptions to an infringement of performers' rights and these exceptions can be made in connection with the copyright protection and copyright exceptions [111]. The Thai legislators followed this approach by connecting the exceptions to the protection of performers' rights with the copyright exceptions. Consequently, the exceptions to the performers' rights function in the same way as the copyright exceptions, which mean that in order to be exempted, such act must first satisfy two preconditions in section 32 paragraph 1 . This paragraph requires: 1 ) such act must not conflict with a normal exploitation of the copyright work by the copyright owner and 2) it must not unreasonably prejudice the legitimate right of the copyright owner [112]. These preconditions for copyright exceptions came from the second and third conditions of the three step test in Article 13 of the TRIPs Agreement and Article 9(2) of Berne Convention and must apply mutatis mutandis to performers' rights under section 52 of the Thai CA 1994 [113].

The three step test does not only appear in the TRIPs Agreement and Berne Convention [114], but also appears in Article 16(2) of the WPPT, which requires that: 1) the exception to the rights provided in the WPPT must confine to certain special cases; 2 ) it must not conflict with a normal exploitation of the performance or phonogram; and 3 ) it does not unreasonably prejudice the legitimate interests of the performer or the producer of the phonogram [115]. This means that the three step test does not only apply to the copyright exceptions, but also apply to the exceptions to the performers' rights. Further, such test also appears in the US FTAs. For instance, the SingaporeUS FTA and the Australia-US FTA allow the contracting countries to provide the exception to the exclusive right of performer by stipulating that contracting parties must confine limitations or exceptions to exclusive rights to certain special cases which do not conflict with a normal exploitation of the performance or phonogram, and do not unreasonably prejudice the legitimate interests of the right holder [116]. Another provision in the Singapore-US FTA that contains the three step test is the provisions relating to the right of authorizing the communication or making the performances available to the public in Article 16.4 (2)(a), which allows the contracting parties to provide exceptions or limitations with respect to non-interactive transmissions in certain special cases provided that such exceptions or limitations do not conflict with a normal exploitation of performances or phonograms and do not unreasonably prejudice the interests of such right holders [117]. 
In theory, the exceptions for performers' right under the CA 1994 seems to comply with the three step test in Article 16(2) of the WPPT since the Thai legislators had inserted the second and third criteria of the three step test into paragraph 1 of section 32 of the CA 19994 as precondition for the exceptions. Also, these exceptions seem to comply with the first criteria of the three step test which requires that the exception must confine to certain special case. In this instance, most exceptions in the CA 1994 require that in order to be exempted from an infringement of performers' rights, such act must first satisfy two preconditions and then it must either satisfy additional conditions in paragraph 2 of section 32 which provides the list of the permitted acts or additional conditions in the specific exceptions [118]. The exceptions under the CA 1994 seems to have less problematic with the three step test than that of US fair use, which was criticized by many scholars as a broad criteria that does not satisfy the three step test since it does not limit to certain special cases [119].

The function of the exceptions which apply to performers' rights can be divided into two categories. The first category is the exceptions on the list of the permitted acts in section 32 paragraph 2, which allows eight purposes of uses to be exempted from the infringement of copyright and all of these permitted acts could be applied mutatis mutandis as the exceptions to the infringement of performers' right [120]. Some of these permitted acts also appear in Article 15(1) of the Rome Convention. For example, the use for research and study in paragraph 2(1), the uses for new reporting in paragraph 2(4), the use for the teaching purpose in paragraph 2(6) are the same as the permitted purposes of uses in Article 15(1)(a), (b) and (d) of the Rome Convention [121].

The second category is the specific exceptions in sections 33,34 , 36,42 , and 43 . The application of the specific exceptions in relation to performers' rights is quite limited. Although the Thai CA 1994 provides ten specific exceptions for copyright, only five specific exceptions could be applied to performers' rights. They are the exception for use as reference in section 33; for use by librarian in section 34; for the uses of dramatic or musical works for public performance in section 36; for use of cinematographic work in section 42 ; and for government use in section 43

Since both categories require the two preconditions to be satisfied together with other additional conditions in each exception, it can ensure that the exceptions in the CA 1994 which apply to performers' rights are fully complied with the three step test in both the TRIPs and the WPPT. For example, the specific exception for the uses of dramatic or musical works for public performance in section 36 also require two preconditions to be satisfied together with four additional conditions: 1) the public performance must be appropriate and is not organized or conducted for seeking profit from such activity; 2 ) it is organized or conducted without direct or indirect charge; 3) the performers of that public performance have not received remuneration for their performance; 4) it is conducted by an association, foundation or another organization having objectives for public charity, education, religion or social welfare.

In practice, the application of the two preconditions in section 32 paragraph 1 , which normally apply together with other additional conditions in the exceptions on the list of permitted acts and specific exceptions, seem to be very problematic in practice because they are unclear and uncertain [122]. This is because such application of these preconditions in the context of performers' rights raises the question of what amount of reproduction of the fixation of performance could be considered as 'not in conflict with a normal exploitation of the copyright work' and 'not unreasonably prejudicial to the legitimate right of the copyright owner'[123]. There is no exact meaning of the phrases in the two preconditions, so it depends on the assessment of the Thai court, determining case by case, whether the amounts reproduced are in conflict with a normal exploitation and unreasonably prejudicial to the legitimate right of the performers [124].

Consequently, this would normally affect the operation of the exceptions which rely on the two preconditions [125]. For instance, the specific exception for the reproduction by librarians in section 34 also has the same problem as other exceptions under the CA 1994 which are subject to the two preconditions in section 32 paragraphs 1 . In this instance, when applying the exception for reproduction by libraries in section 34(2) in the context of performers' right, the exception allows the librarian to reproduce part of a fixation of performance for another person for the purpose of research and study, provided that such reproductions is not for profit and the two preconditions in section 32 paragraph 1 are complied with. Since this exception is subject to the two conditions in section 32 paragraph 1 , the un-clarity and ambiguity of the two preconditions also affect this exception when it applies to copyright or when it applies mutatis mutandis to the performers' rights. In this vein, this exception does not have a clear limitation as to the permissible amount of reproduction of the fixation of performance or phonogram by librarian because it is unclear when and to what extent the reproduction of such fixation of performance or phonogram by libraries can be considered as in conflict with a normal exploitation of the performance or phonogram and unreasonably prejudicial to the legitimate right of the performers. Also, the language of the provision does not prohibit the librarian from making multiple and systematic reproduction of the fixation of performance or phonogram for the students. The similar problem also occurs with other exceptions which require the two preconditions to be satisfied as well.

The recent decisions on exceptions of the Thai courts do not seem to help in interpreting or defining the exact meaning of the two preconditions [126]. They seem instead to create more misunderstanding about the amount of reproduction under the exceptions [127]. This is because none of these judicial decisions of the Thai courts indicates that multiple reproductions of the fixation of performance or phonogram or copyright works by the users, institutions and teachers are in conflict with a normal exploitation of the work, performance or phonogram and unreasonably prejudicial to the legitimate right of the performers or copyright owners [128]. On the other hand, the approach of the Thai courts in several decisions on the exceptions seems to allow users or students to make multiple reproductions of the works, the fixation of performance or phonogram [129]. Hence, the exceptions under the Thai CA 1994 are not only a problem in themselves, but also the approach of the Thai courts in several decisions which allow the multiple and systematic reproductions is also a significant factor undermining the effectiveness of the protection of the performers' rights and copyright in Thailand [130]. The fact that multiple and systematic reproductions of the fixation of performance, or phonogram or copyright materials by the users, students and librarians can be done under the current exceptions, is evidence of inadequate protection for the economic interests of the performers and copyright owners.

This article recommends that the following tasks must be taken in order to solve these problems. First, the two preconditions in section 32 paragraph 1 of the CA 1994 should be removed from the provisions of the exceptions to performers' rights and copyright. As already noted, the Thai legislators chose a convenient way to ensure that the CA 1994 fully complied with the obligation under the TRIPs Agreement 
by simply inserting the second and third conditions of the threestep test into the Act and then regarding them as preconditions to all exceptions relating to both performers' rights and copyright. This leads to further problems because the meaning of the two preconditions are unclear, so it affects the operation of other exceptions in the Act, which normally require the two preconditions to be satisfied together without other additional conditions. Also, regarding these conditions of the three-step test as the exception to performers' rights and copyright is clearly inconsistent with the objective of the three step test, which is to impose constraints on the exceptions to exclusive rights of performers and copyright owners in national copyright laws rather than acting as the exceptions themselves [131]. This also makes it more difficult for the national courts to interpret the two conditions because these criteria of the three-step test have been interpreted by the relevant international bodies such as the WTO Panel [132]. Hence, if the national court interpreted these two conditions in an opposite direction to the decisions of the WTO Panel, it might face challenge from other countries in the WTO dispute settlement proceeding [133]. Even if the Thai court attempted to interpret these conditions consistent with the decisions of the WTO Panel, the problem of the ambiguity and the uncertainty of the provision still remain since the WTO Panel interpreted the three-step test broadly, so there remain doubts about the meaning of the test [134]. Therefore, the insertion of these conditions of the three step test into the national copyright legislation and then regard them as the exceptions in their own right results in more problems for Thailand.

Second, the insertion of a clear prohibition on multiple reproductions or a clear limitation as to the amount of reproduction of the fixation of performance or phonogram into the exceptions in the list of permitted acts in section 32 paragraph 2 and specific exceptions which also apply mutatis mutandis to performers' rights must be done. For the specific exception, such change and insertion must be made to the exception for use as reference in section 33; for use by librarian in section 34; for the use of dramatic or musical works for public performance in section 36; for use of cinematographic work in section 42 ; and for government use in section 43 . Without a clear prohibition on multiple reproductions and clear limitation as to the amount of reproduction of the fixation of performance or phonogram, there is a possibility that the provisions on the exceptions to performers' rights would be interpreted to allow users to reproduce the fixation of performance or phonogram under the exceptions regardless of whether such reproduction impairs the economic interest of performers. This view is supported by several IIPA reports, which illustrate that the increased quantity of the infringement of copyright and related rights in Thailand results from the lack of a clear prohibition on multiple reproductions and clear limitation as to the amount of reproduction of such materials and the misinterpretation of the three-step test by the Thai courts [135].

Final, this article recommends that the formulation of the guideline on the reproduction of the fixation of performance or phonogram under the exceptions to performers' rights would be very useful for Thailand because it can ensure some degree of certainty for institutions [136], teachers, librarians and users by providing assistance in determining what amount of reproduction of the fixation of performance or phonogram can be reproduced under the exceptions [137]. However, such guideline should reflect the interests of performers and other interest groups in society, which means that all interested parties should be able to participate in the creation of such guideline and it should not be formulated by copying or imitating from the guidelines of other countries. This is because if all such groups are involved, it is likely that they will accept the amount of permissible reproductions and other provisions which they all agreed.

In past, the Department of Intellectual Property (DIP) in Thailand has formulated several guidelines on copyright, but they are not widely acceptable because the DIP did not allow all interested parties such as users, copyright owners and publishers to participate in the process of creating the guideline and thus, the guideline has little use in practice since it does not reflect the interests involved. In order to solve this problem, the IIPA requested in several of its reports that the affected parties such as the US right holders which have more experience in creating similar guidelines for other countries should be permitted to participate in the formation of such guidelines [138]. This lesson can be applied in the context of the guideline relating to performers rights. In this instance, if the DIP intends to formulate the guideline relating to the reproduction of the fixation of performance or phonogram and wants such guideline to be widely recognized by all affected parties, then it is necessary for the DIP to ensure that its guideline reflects the interests of performers and other interest groups such the users. This will also help to solve the problem about how much of the fixation of performance or phonogram can be reproduced under the exceptions, while at the same time provide great assistance for all users, institutions and librarians. The formulation of guidelines which reflect the interests of the performers and other groups of interests in Thailand should be done alongside the changes and improvements of the exceptions relating to performers' rights under the Thai CA 1994.

\section{The Protection for the Technological Protection Measures (TPMs) of Performers}

At present, the protection of performers' right under the Thai CA 1994 is still inappropriate because it cannot protect the performers' rights in the digital environment. It is undeniable that technological development has increased the demands for the protection of performers' rights in the digital environment because these digital technologies have affected Thai performers in many ways. For example, they increase the opportunities and means of experiencing performances via recording without attending a live performance as well as increasing the numbers of products and services focused on entertainment at home rather than in public places such as recording of the performances for later viewing.

The digital technologies extend the forms of dissemination of recorded performances to the public and have led to changing methods of dissemination to the public such as transmission via computer network and digital broadcasting [139]. This means that the opportunities for new uses or reuses of recorded performances would be increasing. For example, the services such as computer network services will also increase the opportunities for new uses and reuses of recorded performances. These technologies are likely to mean that the performers' ability to derive economic and financial benefits from their performances will be severely limited unless they have more appropriate means to deal with these new modes of distribution. The WPPT seems to be a solution for Thailand because it provides higher standard for the protection of performers' rights especially in the digital environment. This is because the WPPT contains the provisions on the protection of the technological protection measure (TPM) and also the right management information (RMI) for performers, which will help to protect the performers' rights in the digital environment more effectively.

Further, most US FTAs do not only require contracting countries including Thailand to ratify the WPPT which contains the TPM and 
RMI provisions, but also specifically require the contracting countries to provide the protection for TPM and RMI in accordance with their specific provisions on the protection of the TPM and RMI for the performers. These TPM and RMI provisions in the US FTAs have been highly influenced by the Digital Millennium Copyright Act of the US [140]. Currently, the CA 1994 does not contain any provision on the protection of the TPM and RMI. Hence, since both the WPPT and the US FTA contain the TPM and RMI provisions, Thailand would eventually need to insert such provisions into the CA 1994 after it ratifies the WPPT or signs the FTAs with the US. This section will consider the issue relating to the TPM, while the issue relating to the RMI will be discussed in the next section.

The TPM provisions in the US FTAs consist of the anticircumvention provision and the anti-trafficking provision. First, the anti-circumvention provisions in the US FTAs prohibit the circumvention of any TPM that effectively controls access to the protected works, performances, phonograms or other subject matter in digital form [141]. These provisions in all US FTAs are nearly identical to each other since they require the contracting countries to provide an adequate protection and effective legal remedies against the circumvention of effective TPMs that performers and copyright owners use in connection with the exercise of their rights and that restrict unauthorized acts in respect of their works, performances, and phonograms [142]. In this instance, contracting countries must provide that any person who knowingly or having reasonable ground to know, circumvents any effective TPM that controls access to a protected work, performance, phonogram, or other subject matter without authority shall be liable [143]. The term 'effective technological measures' is defined in these US FTAs as any technology, device or component that controls access to a protected work, performance, phonogram, or other subject matter in the normal course of its operation [144]. The circumvention of an access control means disabling copy-protection mechanisms or any activity that makes circumvention possible, including the sale of devices that can be used to circumvent the TPM [145]. In other words, these TPM provisions only concern the act of passing the barrier of the locked program and the TPM that effectively controls access itself, but does not concern the infringement of performers' rights or copyright that might occur once the protected works, performance, or phonogram has been accessed [146].

Second, the anti-trafficking provisions in the US FTAs prohibit the manufacture or the distribution of any device, which is primarily used to circumvent a TPM that effectively controls access to a protected work, performance, phonogram, or other subject matter [147]. Normally, the US FTAs identically require a contracting countries to provide for the liability of any person who manufactures, imports, distributes, offers to the public, provides or traffics in devices, products, or components or offers to the public or provides services which are promoted, advertised, or marketed for the purpose of circumvention of any effective TPMs, or which have only a limited commercially significant purpose or use other than to circumvent any effective TPMs, or which are primarily designed, produced, or performed for the purpose of enabling or facilitating the circumvention of any effective TPMs [148]. These TPM provisions aims to prohibit the devices and services that circumvent a TPM or that are primarily designed or produced to circumvent, or are marketed for use in circumventing effectively controls access to a protected work, performance, phonogram, or other subject matter [149].

In contrast, the EU FTAs also contain similar TPM provisions to that of the US FTAs, but the only difference is that the scope of such provisions is still unclear because wording in these provisions raises the question of whether such provisions can apply to performers' rights. For instance, Article 5.7 of the draft of the EU-ASEAN FTA define the expression 'technological measures' as 'any technology, device or component that, in the normal course of its operation, is designed to prevent or restrict acts, in respect of works or other subject matter, which are not authorized by the right holder of any copyright or any right related to copyright as provided for by law' [150]. The phrase 'the right holder of any copyright or any right related to copyright' indicates that such provision might only apply to the right holder of copyright or the right relating to copyright, but not to performers' rights, or other neighboring rights which are not related to copyright. Nevertheless, the EU FTAs require the contracting countries to ratify the WPPT, so the contracting countries would have to provide the protection for the TPM of the performers in accordance with the WPPT.

Nevertheless, it is important to note that the TPM provision in the WPPT is quite different from those in the US and EU FTAs because it is more flexible than those in the US and EU FTAs. Pursuant to Article 18 of WPPT, the contracting countries must provide adequate legal protection and effective legal remedies against the circumvention of effective TPM that are used by performers in connection with the exercise of their rights and that restrict acts, in respect of their performances or phonograms, which are not authorized by the performers or permitted by law [151]. Although the WPPT also requires contracting countries to provide adequate legal protection against circumvention, such provision leaves much room for contracting countries to define the content and scope of the new form of protection subject to the minimum standards set forth in the WPPT. This is different from the TPM provisions under the FTAs, which seem to be stronger and not to provide much freedom for contracting countries to create the appropriate protection for the TPMs along with the exceptions. For instance, the WPPT does not make clear whether or not activities such as the manufacture and trafficking of circumvention devices should be prohibited by domestic copyright laws or, if such activities should be prohibited, how a prohibition should be laid down [152]. Thus, contracting countries have more room to design the protection as well as the exception. This is different from the TPM provisions in the US FTAs that went far beyond the requirements under the WPPT regarding the regulation of circumvention of TPMs by prohibiting the manufacture and distribution of devices which are mainly designed to circumvent [153]. However, it is likely that the prospective ThailandUS FTA would require Thailand to provide adequate protections against actions or devices that circumvent the TPMs as well.

The current provisions on the protection of performers' rights under the CA 1994 is not enough to protect the economic interest of the performers where their performances or phonograms are distributed and made available online in digital form. This is because the current provisions cannot prevent the act of circumvention of the TPMs for performers. Presently, the current Thai CA 1994 does not mention about the protection of TPMs at all, so the act of circumvention of the TPMs can be done freely, so this article recommends that the provisions on the protection of the TPMs for performers should be introduced into the Thai CA 1994 in order to ensure that phonograms or performances of performers will be protected in the digital environment and also there would be no point in having TPMs or security system if anyone can circumvent them freely without any restriction or legal control.

Although TPMs can be very useful in protecting the economic interest of performers by allowing them to control access or to place a limit on who could access the performances or phonograms in the 
digital environment, they can pose a real threat to non-infringing uses under the exceptions to performers' rights. It is necessary for the Thai government to be aware that the possible impacts of the TPM provisions such as those in the FTAs can potentially undermine noninfringing uses under the exceptions to performers' rights. The TPM provisions can potentially prevent the exercise of non-infringing uses under the exceptions by allowing the performers to use the TPMs to prevent users from access to the performances or phonograms in the digital form or to decide whether or not the users can use the performances or phonograms within the exceptions to performers' rights [154]. Therefore, the performances or phonograms in the digital form which users can use for free under the exceptions to performers' rights might be constrained by the TPM provisions. It is likely that the distribution of the performances or phonograms facilitated by the TPMs will be based upon payment for access, so those who cannot afford to pay will be excluded from access [155]. This already happens in the case of copyright, where the TPM provisions prevent the exercise of non-infringing uses under the copyright exceptions by allowing the copyright owners to use the TPMs to prevent users from access to the copyright materials [156]. With this approach, non-infringing uses under the exceptions to performers' rights could probably be excluded, so there is a strong possibility that public interest could be undermined [157]. In order to ensure that the TPMs provisions will not undermine non-infringing use under exceptions to performers' rights, it is necessary for Thailand to develop the exceptions to performers' rights alongside the TPM exceptions. This can be done under the WPPT and most US FTAs, which allow the contracting countries to provide the exceptions to the anti-circumvention provision [158] and the antitrafficking provision. Therefore, the exceptions to the TPM provisions should ensure that all non-infringing uses under the exceptions to performers' rights will be exempted from the violation of the TPM provisions.

\section{The Protection of the Rights Management Information (RMI) of Performers}

The electronic rights management information system (RMIs) is information that identifies the works, authors, performances, and performers, but may also include terms and conditions of use associated with the works, performances, copies of fixed performances or phonograms or the details of a license already granted, or the information about how a license can be obtained. RMIs may take a form of digital numbers or codes representing information which identify the works, performances, phonograms, performers or information relating to the terms and conditions of use, and RMIs may comprise a hyperlink or link to database or websites which contain more information about the works, performances, copies of fixed performances, or phonograms. Since RMI contains information about the works, performances, or phonograms and right holders including performers, it is very important for the electronic distribution and the circulating of the works, performances, or phonograms in the digital environment because it facilitates the search for right holders or performers.

The provision on the protection of the RMI in Article 19(1) of the WPPT requires the contracting parties to provide adequate and effective legal remedies for the protection of the RMI. The similar provisions also appear in the US and EU FTAs. First, Article 19 of the WPPT provide protection for RMI against a person, who knowingly and without authority, removes or alters electronic RMI which is associated with performances, copies of fixed performances or phonograms. This provision contains the same knowledge requirement as the RMI provisions in the US and EU FTAs because it also requires that in order to be liable under this provisions, a person must know or have reasonable grounds to know that such a removal or alteration of RMI could induce or facilitate an infringement of performers' rights or any rights as provided by law. Second, they provide protection for RMI against a person who knowingly and without authority, distributes, imports for distribution, broadcast or communicates or makes available to the public of the performances, copies of fixed performances or phonograms from which electronic RMI has been removed or altered without authority. In order to be liable under these provisions, a person must know or have reasonable ground to know that such distribution, importation for distribution or communication of performances, copies of fixed performances or phonograms, which the RMI has been removed or altered, would induce or facilitate an infringement of performers' rights.

This article points out that the standard of the RMI protection for performers under the US FTAs seems to be enough for Thailand because it meets the minimum standard of RMI protection under Article 19 of the WPPT. In this instance, all US FTAs require the contracting parties to ratify and implement the WPPT as the first international agreement which provided the protection for RMI of the performers, aimed at protecting the new technical methods for identification of the performance, copies of fixed performances or phonograms. In general, the US FTAs divide the RMI prohibition into three parts: 1 ) a person who knowingly removes or alters any RMI should be liable; 2 ) a person who distributes or imports for distribution RMI knowing that the RMI has been removed or altered without authority should be liable; 3) a person who distributes to the public, imports for distribution, broadcasts, communicates, or makes available to the public of the performances, copies of fixed performances or phonograms, knowing that RMI has been removed or altered without authority, should be liable.

Nonetheless, these RMI provisions in the WPPT, EU and US FTAs have one thing in common: they do not require the performers to attach RMI to the performances in digital form, copies of fixed performances or phonograms and so on. For example, Article 19(2) of the WPPT states that RMI means information that identifies the performers, the performances of the performers, the producer of the phonogram, the phonogram, the owner of any right in the performances or phonograms and any numbers or codes that represent such information when any of these items of information is attached to the performances, copies of fixed performances or phonograms or appears in connection with the communication or making available of the performances, copies of fixed performances or phonograms to the public. However, this does not require the performers to attach RMI to the performances, copies of fixed performances, or phonograms. Similarly, the RMI provisions in most US FTAs and the EU FTAs also require that RMI must be associated with the performances, copies of performances or phonograms, or appears in connection with the communication to the public of the performances, copies of performances or phonograms but they will not oblige the contracting parties to require the performers to attach RMI to the performances, copies of performances or phonograms or to cause RMI to appear in connection with a communication of the performances, copies of performances, or phonograms in the digital environment. The WIPO observed that the reason for not creating such an obligation is because it does not want to impose formalities which would impede the enjoyment of rights, and would be against the principle of not requiring formalities for the protection of copyright and performers' rights. 
The provision for the protection of the RMI is quite important for Thailand because RMIs can help right holders and performers to protect their exclusive rights because RMIs can be used to track such illegal activities in the digital environment. For instance, RMIs can be 'tags' or 'fingerprints' included in copies of the works, performances or phonograms in the digital environment, enabling them to be traced and identified electronically wherever the copies of the works, performances or phonograms may be in use. It is important to note that such illegal activities in relating to the removal and alteration of RMI must be prohibited under the RMI provisions because such activities can undermine the functioning of the internal market of the countries. Pursuant to Recital 56 of the EU Copyright Directive, there is the danger that illegal activities might be carried out in order to remove or alter the electronic RMI attached to the works or other protected subject matter, or to distribute, import for distribution, broadcast, communicate to the public or make available to the public of the works or other protected subject matter from which such information has been removed without authority, so in order to avoid fragmented legal approaches that could potentially hinder the functioning of the internal market, the Recital 56 indicates that it is necessary to provide for harmonized legal protection against any of these activities. Nevertheless, the idea behind protecting the RMI is to protect the information and data itself, so the only significant act is the removal or alteration of the identifying information about the works, performances, or phonograms. This means that the RMI which provides evidence of alterations of the copies of the works, performances or phonograms in the digital environment must also include some digital identifying information such as the title of the works, performances, phonograms, name of performers, or identifying numbers, in order to be protected under the RMI provisions.

The RMI provision is not only important in protecting exclusive rights of performers and the functioning of the internal market but also necessary in protecting the moral rights of performers. As already discussed in the previous section, moral rights generally include the rights of attribution and integrity. This right of attribution enables the performers to claim to be identified as the performers of their performances and thus oblige others to communicate these performances under their name, while the right of integrity entitles performers to oppose any alteration or distortion of their performances that prejudices their reputation. Both rights are recognized under Article 5(1) of the WPPT which provides that the performers shall have the right to claim to be identified as the performers of their performances and to object to any distortion, mutilation or other modification of their performances that would be prejudicial to his reputation. However, the moral right of performers is not recognized in section 18 of the Thai CA 1994, which only provides the protection of moral rights for authors.

The RMI provision plays an important role in protecting both the moral right of attribution and integrity of performers. For example, the moral right of attribution is protected under the RMI provisions in all US FTAs because by defining the term 'RMI' as information which identifies the works, performances, or phonograms, the author of the work, the performer of the performance, or the producer of the phonogram, or the owner of any right in the works, performances, or phonograms, these provisions prohibit the removal of the name of the performers and the distribution of the performances from which the performer's name have been removed. The similar definition of RMI can also be found in Article 19(2) of the WPPT, which define the term 'RMI' as information which identifies the performer, the performance of the performer, the producer of the phonogram, the phonogram, the owner of any right in the performance or phonogram. Likewise, the draft of the EU-ASEAN FTA also defines the term "RMI" in Article 5.8(2) to include any information provided by right holders which identifies the work or other subject-matter referred to in this Agreement, the author or any other right holder. The term "any other right holder" in this draft can be interpreted to include performer, who is the owner of performers' rights. With these definitions, such the removal of the name of the performers from the performance in the digital form can be prohibited.

Further, the definitions of the term 'RMI' in the US FTAs also extend to include information about the terms and conditions of the use of the work, performance, or phonogram, and any numbers or codes that represent such information. Similarly, the draft of the EUASEAN FTA also defines the term "RMI" to include information about the terms and conditions of use of the work or other subject-matter, and any numbers or codes that represent such information. The similar definition also appears in Article 19(2) of the WPPT, which defines the term "RMI" to include information about the terms and conditions of use of the performance or phonogram, and any numbers or codes that represent such information. These provisions identically prohibit the removal of the terms and conditions of the use of the performance and any numbers or codes that represent such information as well as forbidding the distribution of a copy of performance or a phonogram from which these information on terms and conditions have been removed. Thus, the RMI provision frequently serves as a means of compliance with the moral right of attribution for performers.

Not only does the RMI provision support the moral right of attribution but it also promotes the moral right of integrity against any distortion, mutilation or other modification of the performance or phonogram that damage the reputation of the performers by ensuring that the performances, copies of fixed performances or phonograms distributed in the digital environment have the same content as the original released by the performers. In practice, RMIs can be intentionally altered by changing the text of the information or by changing the work, performances, copies of fixed performances or phonograms to which the information applies so that the information no longer accurately describes the work, performances, copies of fixed performances or phonograms. These unauthorized alterations to the contents can threaten the credibility of both the performance and the performer's reputation, so the RMI provision is essential in ensuring that information about the works, performances, copies of fixed performances or phonograms and performers is accurate and reliable.

Nevertheless, although the moral right is recognized by the RMI provisions, its application is not autonomous because the moral right in the RMI provisions mainly relies and depends on an infringement of the performers' rights, since most RMI provisions will only apply if the removal or alteration of the RMI facilitates such infringement. For instance, Article 19(1) of WPPT requires the contracting parties to prohibit unauthorized removal or alteration of RMI when a person knows or has reasonable grounds to know that such removal or alteration will induce, enable, facilitate or conceal an infringement of any right covered by the WPPT. These RMI provisions intend to protect any right covered by the WPPT, including both economic rights and moral rights of performers, from the removal and alteration of RMI. Similar terms and conditions also appear in the RMI provisions of the US FTAs, which indicates that in order to be liable, a person must act without authority and knowing or having reasonable grounds to know that it would induce, enable, facilitate or conceal an infringement of any copyright or related rights including performers' rights. It is clear that most RMI provisions are tied directly to the existence of a valid 
right under national laws or international treaties so that they will allow for the removal or alteration of such RMI if the legal protection for such work, performance, or phonogram is non-existent. Hence, it must be shown to the court that such removal or alteration of the RMI facilitates infringements of exclusive rights of performers or other rights such as moral rights of performers.

If the RMI provision in the WPPT and the US FTAs is implemented in Thailand, this concept will also be applied, which means that such provisions will take effect when there is clear evidence that such removal or alteration of the RMI facilitates infringement of performers' rights or any other rights under the Thai CA 1994. But, if there is no evidence that such removal or alteration of the RMI facilitates infringement of performers' rights or any other rights such as moral rights, then there would be no violation of these RMI provisions even if a person willfully intends to violate moral right principles by removing the RMI identifying the performers from the works, performances, or phonograms. For instance, section 44 of the Thai CA 1994 provides that the performer has the exclusive rights in respect to their performance and section 45 provides that performer had the right to remuneration, but these sections are operated in connection with section 52 which provides that 'whoever acts as specified in section 44 without the consent of the performer or without paying remuneration in accordance with section 45 shall be deemed to infringe the performer's rights'. This means that the exclusive right to recording performances or reproduction of performances, copies of fixed performances or phonograms resides with the performers since these provisions require the prior permission of the performers before any reproduction of the performances, copies of fixed performances or phonograms can be done. Such reproduction could result in the infringement of performers' rights under the Thai CA 1994 if the performer did not give prior consent.

However, section 44 and section 45 of the CA 1994, which provides protection for performers' rights, do not mention the right to alteration or adaptation of performances, copies of fixed performances or phonograms. This means that such alteration or adaptation of the performances, copies of fixed performances or phonograms of performers may not result in an infringement of performers' rights under section 52 of the Thai CA 1994. This is different from section 15 of the CA 1994, which guarantees that the copyright owners have the exclusive right to alteration or adaptation of copyright works as well as requiring the prior permission of the copyright owners before any alteration or adaptation can be done to the copyright works. The same protection does not appear in the provisions on the protection of performers' rights in section 44, section 45 and section 52 of the Thai CA 1994. This means that alteration of the performances, copies of fixed performances or phonograms could not result in infringement of performers' rights under the CA 1994.

Further, since the performers cannot rely on the moral right provision in section 18 of the Thai CA 1994 which only provides the protection for moral right of author, this would also affect the application of the prospective RMI provision as well. In this instance, if a person removes RMI such as the performer's name from the performances in the digital form or copies of fixed performances, then it will not constitute an infringement of moral rights under section 18 because this section does not provide any protection for the moral rights of performers. Consequently, it will not meet the requirement that such act must facilitate an infringement of any rights under the Copyright Act. Thus, the introduction of the prospective RMI provisions in Thailand must be done together with the introduction of the provisions on the protection of moral rights of performers. With this proposed change, it will help to promote the protection of moral rights of attribution and integrity in both general context and the digital environment.

It is important to note that although the draft of the EU-ASEAN FTA also contains similar RMI provisions to that of the US FTAs, the scope of the RMI provision in the draft seems to be different from that of the US FTAs and the WPPT. In this instance, the application of Article 5.8 of the of the EU-ASEAN FTA seems to be narrower than that of the US FTAs and the WPPT since its wording seems to be limited to the right related to copyright. In this vein, in order to be liable under Article 5.8(1) of the Draft of the EU-ASEAN FTA, it requires that such person knows or has reasonable grounds to know that such removal or alteration or distribution is inducing, enabling, facilitating or concealing an infringement of any copyright or any rights related to copyright as provided by law. The condition that such removal or alteration must constitute an infringement of any copyright or any rights related to copyright in order to be liable, does not support the protection of the RMI for performers because it can be interpreted to exclude an infringement of performers' rights from the scope of the provision. This is because even if the removal or alteration of the RMI constitutes an infringement of performers' rights, such provision may not apply if such infringement of performers' right is not related to copyright. Therefore, the standard of the RMI protection for performers under the US FTAs and WPPT seems to be clearer and better for Thailand than that of the EU FTAs.

\section{Conclusion}

The current provisions on the protection of performers' right under the Thai CA 1994 is outdated and ineffective in protecting the performers' rights and still fall short of the standard for the protection of performers' rights under the WPPT and prospective FTAs of the US and EU in many areas. Thus, if Thailand is going to ratify the WPPT and sign the FTAs with the US and EU, Thailand needs to prepare for the new standard for the protection of performers' rights. The following changes would need to be made to the provisions on the protection of performers' rights in the Thai CA 1994 in order to make them compatible with the standard of the WPPT and the prospective US FTA and EU FTA.

First, the scope of the term 'performer' in the Thai CA 1994 should be extended to cover 'expressions of folklore' in order to make it compatible with the standard of the term 'performer' in the WPPT, the prospective US FTA and EU FTA.

Second, Thailand should follow the approach in the EU FTAs, which explicitly prevents the exclusive right of authorizing the broadcasting and communication to the public from applying where the performance is already a broadcast performance or is made from a fixation or a recording material. In this instance, Thailand should add one condition into section 44(1) that such provision does not apply where the performance is already a broadcast performance.

Third, regarding the exclusive right of authorizing the recording or the fixation of the unfixed performances in section 44(2), Thailand should define the term "recording" or replacing the term "recording" with the term "fixation" together with the insertion of the clear definition of the term "fixation" - either way it is necessary to ensure that the definition of such term must carry the same meaning and scope as those in the WPPT and the FTAs of the EU and the US.

Fourth, Thailand should expand the scope of the reproduction right of performers in section 44 of the Thai CA 1994 to cover direct 
and indirect reproduction of the performances fixed in phonograms in any manner or form, including temporary reproduction in accordance with Article 7 of WPPT. Nevertheless, if Thailand is going to extend the scope of the reproduction right to cover the temporary reproduction, it is necessary for Thailand to provide the exception to allow certain acts of temporary reproduction in order to ensure that the reproduction right of performers would not affect the function or operation of the new digital technologies.

Fifth, new exclusive rights of performers contained in the WPPT such as the right of distribution in Article 8, right of rental in Article 9, the right of making the fixed performances available to the public in Article 10, would need to be added into the provision on the protection of performers' rights under the Thai CA 1994.

Sixth, the provisions on the protection of moral rights of performer would need to be introduced into the Thai CA 1994 in accordance with Article 5(1) of WPPT.

Seventh, although the term of the protection for performers' rights under the Thai CA 1994 has already satisfied the standard of protection under the WPPT and the prospective EU FTAs which provides the term of the protection of performers' rights for a period of 50 years, it still fall short of the standard of the term of protection under the US FTAs, which provide the term of protection for performers' rights for a period of 70 years. Hence, if Thailand is going to sign the FTA with the US, it would need to extend the term of protection for performers' rights under its copyright law to meet the standard under the prospective US -Thailand FTA.

Eighth, the provisions on the exceptions to performers' rights need to be improved because they are unclear and uncertain. In order to solve this problem of the exceptions, the following tasks must be carried out. 1) the two preconditions in section 32 paragraph 1 of the CA 1994 should be removed from the provisions of the exceptions; 2) a clear prohibition on multiple reproductions or a clear limitation as to the amount of reproduction of the fixation of performances must be inserted into the exceptions in the list of permitted acts in section 32 paragraph 2 and the specific exceptions; 3 ) the formulation of guidelines which reflect the interests of the performers and other groups of interests in Thailand should be done alongside the changes and improvements of the exceptions relating to performers' rights under the Thai CA 1994.

Final, the new provisions on the protection of the TPMs and RMIs of performers would need to be inserted into the provisions on the protection of performers' rights in the Thai CA 1994 in order to comply with the WPPT and the prospective FTAs of the US and the EU.

\section{Acknowledgement}

This article is part of the research project on 'the protection of performers' rights under the copyright law in Thailand'. I owe my deepest gratitude to Faculty of Law, University of Phayao (Thailand) for providing funding and necessary financial support for this research project. I deeply thank Professor Hector MacQueen at the University of Edinburgh for recommending a set of useful research materials and books relating to performers' rights that I used in this research project, but am alone responsible for errors of fact, law and opinion contained within it.

\section{Reference}

1. The World Intellectual Property Organization (WIPO), 'Collective management of copyright and related rights.

2. Arnold R (1997) Performers' rights (2nd edn, Sweet \& Maxwell, London, 1997) at 228 .

3. The Rome Convention is one of the most important treaties providing protection for performers' rights and also it is the first international treaty to grant rights to performers.
4. Bartels L, Ortino F (2006) Regional trade agreements and the WTO legal system, 1st edn, Oxford University Press, Oxford 219-222.

5. Office of the United States Trade Representative (USTR) (2013) Information on the Free Trade Agreement of the US with 20 countries.

6. Department of Trade Negotiation (DTN) Thailand (2013) Free Trade Agreement by country.

7. The US-Chile FTA and the US-Singapore FTA

8. Article 17.1.4 of the US-Australia FTA.

9. Article 16.1.2(a)(iv) of the US-Singapore FTA

10. Article 14.1 of the US-Bahrain FTA

11. Article 15.1 of the US-Morocco FTA.

12. The draft of the EU-ASEAN FTA, Intellectual Property Chapter.

13. Article 5.1 of the draft of the EU-ASEAN FTA, Intellectual Property Chapter.

14. European Commission, International Affairs: Free Trade Agreements.

15. The Association of Southeast Asian Nations (ASEAN), 'ASEAN Intellectual Property Right Action Plan 2004-2010.

16. The Association of Southeast Asian Nations (ASEAN) (2011) ASEAN Intellectual Property Right Action Plan 2011-2015.

17. Section 4 of the Thai Copyright Act 1994.

18. Subhapholsiri D (2001) Copyright Law: the Copyright Act B.E. 2537 (1994), Nititham Publishing House: Bangkok, Thailand, at 283.

19. Pursuant to Article 3(a) of the Rome Convention, the term "performers" is defined as 'actors, singers, musicians, dancers, and other persons who act, sing, deliver, declaim, play in, or otherwise perform literary or artistic works' Similarly, Article 9 of this convention conforms that a contracting state can extend the protection provided for in this Convention to artists who do not perform literary or artistic works in its domestic laws and regulations.

20. Article 2(a) of the WPPT.

21. The World Intellectual Property Organization (WIPO), Diplomatic Conference on the Protection of Audio-visual Performances (2000)

22. Arnold R (1997) Performers' rights, Sweet \& Maxwell, London, at 33.

23. Article 16.5(4) (a) of the US-Singapore FTA and Article 17.6(5) (d) of the USAustralia FTA.

24. In cases where there is more than one performer involved, each performe must be entitled to assign only 'the mere portion of his rights'. However, the assignment of these rights must be made in writing with signatures of the assignor and the assignee and in case the duration is not specified in the assignment contract, the assignment will be for three years. This makes the provisions on the protection of performers' rights of the Thai Copyright Act 1994 compatible with the US FTAs. For instance, Article 16.4(6)(a) of the SingaporeUS FTA requires the contracting parties to guarantee that any person acquiring or holding any economic right relating to copyright and related rights including performers' rights may freely and separately transfer such right by contract.

25. The WPPT strengthens the protection of performers' rights and provides even wider protection than the Rome Convention and the TRIPS Agreement by making its provisions more explicit than these two treaties. This can be seen in Articles $6,7,8,9$, and 10 which use the phrase 'performers shall enjoy the exclusive right of authorizing' rather than the mere 'possibility of preventing' as used in Article 7 of the Rome Convention and Article 14 of TRIPs Agreement.

26. Section 44 of the Thai Copyright Act 1994

27. Subhapholsiri D (2001) Copyright Law: the Copyright Act B.E. 2537 (1994) Nititham Publishing House: Bangkok, Thailand, at 285.

28. Hemaratchata C (2006) Copyright Law, Nititham Publishing House, Thailand at 297.

29. Article 6(i) and (ii) of the WPPT; The World Intellectual Property Organization (WIPO), WIPO Seminar for Asia and the pacific region on the Internet and the protection of intellectual property rights, WIPO/INT/SIN/98/5 (April 1998) Article 2(f) of the WPPT, See also Wan Y (2009).

30. Article 2(g) of the WPPT

31. Ficsor M (1996) the law of copyright and the internet: The 1996 WIPO treaties, 
Citation: Supasiripongchai N (2014) The Protection of Performer's Rights under the Copyright Law in Thailand: The Proposed Reform in the Light of the Prospective Free Trade Agreements with the United States and European Union. Intel Prop Rights 2: 127. doi:10.4172/2375-4516.1000127

their interpretation and implementation, Oxford University Press, USA 2002 at $418,442$.

32. Article 16.5(2) (a) of the US-Singapore FTA and Article 17.6(4) (a) of the USChile FTA.

33. Article 5.5(2) of the draft of the EU-ASEAN FTA, Intellectual Property Chapter, Article 10.9(2) of the EU-the Republic of Korea FTA.

34. Subhapholsiri D (1994) Copyright Law: the Copyright Act B.E. 2537, Nititham Publishing House: Bangkok, Thailand 2001, at 285.

35. Article 6(ii) of the WPPT.

36. Article 16.5(2) (b) of the US-Singapore FTA and Article 17.6(4) (b) of the USChile FTA

37. The World Intellectual Property Organization (WIPO), (1998) WIPO Seminar for Asia and the pacific region on the Internet and the protection of intellectual property rights, WIPO/INT/SIN/98/5.

38. Wan $Y$ (2009) Legal protection of performer's rights in the Chinese copyright law 56 Journal of the Copyright Society of the USA 669, at 675.

39. The World Intellectual Property Organization (WIPO) (1998), WIPO Seminar for Asia and the pacific region on the Internet and the protection of intellectual property rights, WIPO/INT/SIN/98/5.

40. Article 2(c) of the WPPT.

41. The World Intellectual Property Organization (WIPO) (1999), WIPO Semina for Asia and the pacific region on the Internet and the protection of intellectual property rights, WIPO/INT/SIN/99/5.

42. Article 16.5(4) (c) of the US-Singapore FTA and Article 2(c) of the draft of the EU-ASEAN FTA, Intellectual Property Chapter.

43. Section 44(3) of the Thai Copyright Act 1994.

44. Article 14(1) of the TRIPs Agreement and Article 7(1) of the Rome Convention.

45. Article 7 of the WPPT.

46. The World Intellectual Property Organization (WIPO), 'Diplomatic Conference on the Protection of Audiovisual Performances', (Geneva, 7th to 20th of December 2000), Document IAVP/DC/3, at 40.

47. Sterling J (2008) World Copyright Law, Sweet \& Maxwell, London, at 737.

48. Wan $Y(2009)$ Legal protection of performers rights in the Chinese copyright law, 56 Journal of the Copyright Society of the USA 669, at 675

49. Ficsor M (2002) The law of copyright and the internet: The 1996 WIPO treaties, their interpretation and implementation,Oxford University Press, USA, at 624.

50. The World Intellectual Property Organization (WIPO), 'Diplomatic Conference on the Protection of Audiovisual Performances', (Geneva, 7th to 20th of December 2000), Document IAVP/DC/3, at 2.

51. The World Intellectual Property Organization (WIPO), 'Diplomatic Conference on the Protection of Audiovisual Performances', (Geneva, 7th to 20th of December 2000), Document IAVP/DC/3, at 38 .

52. Article 16.4(1) of the US-Singapore FTA and Article 17.6(1) of the US-Chile FTA

53. Article 2(b) of Directive 2001/29/EC of the European Parliament and of the Council of 22 May 2001 on the harmonisation of certain aspects of copyright and related rights in the information society.

54. Article 2(b) of Directive 2001/29/EC of the European Parliament and of the Council of 22 May 2001 on the harmonisation of certain aspects of copyright and related rights in the information society.

55. Preamble (33) of the Directive 2001/29/EC of the European Parliament and of the Council of 22 May 2001 on the harmonisation of certain aspects of copyright and related rights in the information society.

56. Article 16.4(10) of the US-Singapore FTA and Article 17.4(10)(a) of the USAustralia FTA.

57. Article 8(1) of the WPPT.

58. The World Intellectual Property Organization (WIPO), 'Diplomatic Conference on the Protection of Audiovisual Performances', (Geneva, 7th to 20th of December 2000), Document IAVP/DC/3, at 42.
59. Article 16.4(3) of the US-Singapore FTA and Article 17.6(2) of the US-Chile FTA.

60. Article 8(2) of the WPPT

61. Reinbothe J (2004) The WIPO Treaties 1996: The WIPO Copyright Treaty and the WIPO Performances and Phonograms Treaty Commentary and Legal Analysis, Tottel Publishing, London, at 321.

62. Article 9(1) of the WPPT.

63. Article $9(2)$ of the WPPT

64. Article 10 of the WPPT.

65. Sterling J (2008) World Copyright Law, Sweet \& Maxwell, London 2008), at 738.

66. Reinbothe J (2001) the WIPO Treaties 1996: The WIPO Copyright Treaty and the WIPO Performances and Phonograms Treaty Commentary and Legal Analysis, Tottel Publishing, London, at 268.

67. Article 16.4(2) (a) of the US-Singapore FTA and Article 17.6(5) (a) of the USChile FTA.

68. Paragraph 1 of section 45 of the Thai Copyright Act 1994 provides that any person who directly uses a sound recording of a performance, which has been published for commercial purposes or the copies thereof in a broadcast or a communication to the public, is bound to pay an equitable remuneration to the performer.

69. Subhapholsiri D (2001) Copyright Law: the Copyright Act B.E. 2537 (1994) Nititham Publishing House: Bangkok, Thailand at 291.

70. Paragraph 1 of section 45 of the Thai Copyright Act 1994.

71. Paragraph 2 of section 45 of the Thai Copyright Act 1994.

72. Section 46 of the Thai Copyright Act 1994.

73. Article 12 of the Rome Convention, which provides that if a phonogram published for commercial purposes, or a reproduction of such phonogram, is used directly for broadcasting or for any communication to the public, a single equitable remuneration shall be paid by the user to the performers, or to the producers of the phonograms, or to both. The domestic law of contracting countries may, in the absence of agreement between these parties, lay down the conditions as to the sharing of this remuneration.

74. Article 15(1) of the WPPT.

75. Article $15(3)$ of the WPPT.

76. Article 15(2) of the WPPT.

77. Article 5.5(3) of the draft of the EU-ASEAN FTA, Intellectual Property Chapter

78. Article 10.9 (3) of the EU-the Republic of Korea FTA, accessible at (2014).

79. Article 10.9(4) of the EU-the Republic of Korea FTA.

80. Simondson H (2014) Performing arts media library: From live performance to the digital stage' (1999).

81. Article 5(1) of the WPPT

82. Article 5(2) of the WPPT; It is important to note that if at the time of the accession to the WPPT the legislation of the contracting country did not provide protection for the moral rights of performers after the death of the performers, then Article $5(2)$ allows the contracting parties to provide that some of these rights will, after the performer's death, cease to be maintained.

83. Arnold R (1997) Performers' rights, Sweet \& Maxwell, London at 33.

84. Section 18 of the Thai Copyright Act 1994

85. Section 49 of the Thai Copyright Act 1994.

86. Section 50 of the Thai Copyright Act 1994

87. Article 14(b) of the Rome Convention.

88. Article 14(5) of the TRIPs Agreement

89. Garnett K Directive harmonising the term of protection of copyright and certain related rights Copinger and Skone James on Copyright, Sweet and Maxwell, London, 1269 Directive 2001/29/EC of the European Parliament and of the Council of 22 May 2001 on the harmonisation of certain aspects of copyright and related rights in the information society. 
90. Article 16.4(4) of the US-Singapore FTA and Article 17.6(7) of the US-Chile FTA.

91. Article 17(1) of the WPPT and Article 14(5) of the TRIPs Agreement.

92. Section 52 of the Thai Copyright Act 1994

93. Article 15(2) of the Rome Convention.

94. Article 14(6) of the TRIPs Agreement.

95. Article 16(1) of the WPPT.

96. Section 32 of the Thai Copyright Act 1994

97. Supasiripongchai N (2011) Copyright infringement and educational exceptions in Thailand: What should be the solution to the problem of copyright infringement in the Thai education sector?' (2011), in WIPO-WTO Colloquium Papers: Research Papers from the WIPO-WTO Colloquium for Teachers of Intellectual Property Law 2011, (published by the WIPO Academy of World Intellectual property Organization (WIPO) and the Intellectual Property Division of World Trade organization (WTO), Geneva Switzerland, August 2012). 133 -151 , at 135 and 144.

98. Article 13 of the TRIPs Agreement and Article 9 of the Berne Convention.

99. Article 16(2) of the WPPT.

100. Article 16.4(2) (a) of the US-Singapore FTA

101. Supasiripongchai $N$ (2011) The Enforcement of the Copyright law in Thailand: What could be the answer to massive copyright violations in Thailand 33(12) European Intellectual Property Review (EIPR) 795, at 797.

102. Supasiripongchai, N, 'Copyright infringement and educational exceptions in Thailand: What should be the solution to the problem of copyright infringement in the Thai education sector?' (2011), in WIPO-WTO Colloquium Papers: Research Papers from the WIPO-WTO Colloquium for Teachers of Intellectual Property Law 2011, (published by the WIPO Academy of World Intellectua property Organization (WIPO) and the Intellectual Property Division of World Trade organization (WTO), Geneva Switzerland, August 2012). Pages 133 151 , at 140 and 145 .

103.Paragraph 2 of section 32 of the Thai Copyright Act 1994 provides: subject to paragraph one, any act against the copyright work in paragraph one is not deemed an infringement of copyright; provided that the act is each of the followings: (1) research or study of the work which is not for profit; (2) use for personal benefit or for self-benefit together with the benefit of other family members or close relatives; (3) comment, criticism or introduction of the work with an acknowledgement of the ownership of copyright in such work; (4) news reporting through mass media with an acknowledgement of the ownership of copyright in such work; (5) reproduction, adaptation, exhibition or display for the benefit of judicial proceedings or administrative proceedings by authorized officials or reporting such proceedings; (6) reproduction, adaptation, exhibition or display by an instructor for the benefit of instruction provided that the act is not for profit; (7) reproduction, adaptation in part of a work or abridgement or making a summary by an instructor or an educational institution so as to distribute or sell to students in a class or in an educational institution provided that the act is not for profit; (8) use of the work as part of questions and answers in an examination.

104. Article 15(1) of the Rome Convention provides that any Contracting State may, in its domestic laws and regulations, provide for exceptions to the protection under the Rome Convention in the case of (a) private use; (b) use of shor excerpts in connection with the reporting of current events; (c) ephemeral fixation by a broadcasting organization by means of its own facilities and for its own broadcasts; and (d) use solely for the purposes of teaching or scientific research.

105. Supasiripongchai $\mathrm{N}$ (2012) Copyright infringement and educational exceptions in Thailand: What should be the solution to the problem of copyright infringement in the Thai education sector, in WIPO-WTO Colloquium Papers: Research Papers from the WIPO-WTO Colloquium for Teachers of Intellectual Property Law 2011, (published by the WIPO Academy of World Intellectual property Organization (WIPO) and the Intellectual Property Division of World Trade organization (WTO), Geneva Switzerland, August 2012). Pages 133 151 , at 139 to 142 .

106. Supasiripongchai N (2011) 'Copyright infringement and educational exceptions in Thailand: What should be the solution to the problem of copyright infringement in the Thai education sector?' (2011), in WIPO-WTO Colloquium Papers: Research Papers from the WIPO-WTO Colloquium for Teachers of Intellectual Property Law 2011, (published by the WIPO Academy of World Intellectual property Organization (WIPO) and the Intellectual Property
Division of World Trade organization (WTO), Geneva Switzerland, August 2012). Pages 133 - 151, at 139.

107. The IP\&IT Court Decision No. $785 / 2542$ (1999), affirmed in the Supreme Court Decision No. 1772/2543 (2000) - the parties in Decision No. 785/2542 appealed to the Supreme Court and the decision was affirmed by the Supreme Court in the Supreme Court Decision No. 1772/2543(2000); See also the IP\&IT Court Decision No. 784/2542 (1999), revered in the Supreme Court Decision No. 5843/2543 (2000) - the parties in the IP\&IT Court Decision No. $784 / 2542$ appealed to the Supreme Court and the decision was overturned by the Supreme Court in the Supreme Court Decision No. 5843/2543 (2000); See also Supasiripongchai, N, 'Copyright protection in Thailand: Should the establishment of the copyright collecting societies (CCS) and licensing scheme system be the solution to the problem of copyright infringement in the Thai education sector?' (2012), 3 Intellectual Property Quarterly (IPQ) 173, at $174-178$.

108. Supasiripongchai, N, 'Copyright protection in Thailand: Should the establishment of the copyright collecting societies (CCS) and licensing scheme system be the solution to the problem of copyright infringement in the Thai education sector?' (2012), 3 Intellectual Property Quarterly (IPQ) 173, at $174-178$.

109. Supasiripongchai N (2013) 'Copyright Exceptions and Digital Technology in Educational Institutions in Thailand' (2013), 44 (7) International Review of Intellectual Property and Competition Law (IIC) 765-789.

110. The IP\&IT Court Decision No. $785 / 2542$ (1999), affirmed in the Supreme Court Decision No. 1772/2543 (2000) - the parties in Decision No. 785/2542 appealed to the Supreme Court and the decision was affirmed by the Supreme Court in the Supreme Court Decision No 1772/2543(2000); See also the IP\&IT Court Decision No. 784/2542 (1999), revered in the Supreme Court Decision No. 5843/2543 (2000) - the parties in the IP\&IT Court Decision No. $784 / 2542$ appealed to the Supreme Court and the decision was overturned by the Supreme Court in the Supreme Court Decision No. 5843/2543 (2000).

111. Supasiripongchai, N, 'Copyright infringement and educational exceptions in Thailand: What should be the solution to the problem of copyright infringement in the Thai education sector?' (2011), in WIPO-WTO Colloquium Papers: Research Papers from the WIPO-WTO Colloquium for Teachers of Intellectual Property Law 2011, (published by the WIPO Academy of World Intellectual property Organization (WIPO) and the Intellectual Property Division of World Trade organization (WTO), Geneva Switzerland, August 2012). 133 - 151, at 138 to 142

112. Supasiripongchai, N, 'Copyright infringement and educational exceptions in Thailand: What should be the solution to the problem of copyright infringement in the Thai education sector?' (2011), in WIPO-WTO Colloquium Papers: Research Papers from the WIPO-WTO Colloquium for Teachers of Intellectual Property Law 2011, (published by the WIPO Academy of World Intellectual property Organization (WIPO) and the Intellectual Property Division of World Trade organization (WTO), Geneva Switzerland, August 2012). Pages 133 151 , at 144

113. This already happened to the US in the WTO Panel Decision No WT/DS106 where the US had been challenged by the European Commission because its exceptions in section 110(5) do not comply with the three-step test; so the same situation can probably happen to other countries as well.

114. Supasiripongchai $N$ (2011) The Enforcement of the Copyright law in Thailand What could be the answer to massive copyright violations in Thailand?' (2011), 33(12) European Intellectual Property Review (EIPR) 795, at 798.

115. International Intellectual Property Alliance (IIPA), 'International intellectual property alliance 2009 Special 301 Report on Copyright Protection and Enforcement in Thailand.

116. International Intellectual Property Alliance (IIPA), 'International intellectual property alliance 2010 Special 301 Report on Copyright Protection and Enforcement in Thailand.

117. International Intellectual Property Alliance (IIPA), 'International intellectual property alliance 2011 Special 301 Report on Copyright Protection and Enforcement in Thailand.

118. International Intellectual Property Alliance (IIPA), 'International intellectua property alliance 2012 Special 301 Report on Copyright Protection and Enforcement in Thailand.

119. International Intellectual Property Alliance (IIPA), 'International intellectual property alliance 2013 Special 301 Report on Copyright Protection and Enforcement in Thailand. 
Citation: Supasiripongchai N (2014) The Protection of Performer's Rights under the Copyright Law in Thailand: The Proposed Reform in the Light of the Prospective Free Trade Agreements with the United States and European Union. Intel Prop Rights 2: 127. doi:10.4172/2375-4516.1000127

120. The main forms of dissemination of recorded performances to the public are sale of copies of the recorded performances such as compact disc; rental of copies of the recorded performances; broadcast on radio and television playing or showing of recorded performances in the public places.

121. Supasiripongchai N (2013) 'The development of the provisions on the protection of Technological Protection Measures (TPMs) in the light of the prospective Thailand-United States Free Trade Agreement (FTA) and its possible impacts on non-infringing uses under copyright exceptions in Thailand: What should be the solution for Thailand?' (2013), 1 Computer and Telecommunications Law Review (CTLR) 21, at 23.

122. Article 5.7(3) of the draft of the EU-ASEAN FTA, Intellectual Property Chapter.

123. Article 18 of the WPPT.

124. Article 15.5(8)(a)(ii) of the US-Morocco FTA; Article 14.4(7)(a)(ii) of the USBahrain FTA; Article 15.5(7)(a)(ii) of the US-Central American FTA (CAFTA); Article 16.4(7)(a)(ii) of the US-Singapore FTA; Article 17.4(7)(a)(ii) of the USAustralia FTA; Article 17.7(5)(b) of the US-Chile FTA; Article 15.4(7)(a)(ii) of the US-Oman FTA; and Article 16.7(4)(a)(ii) of the US-Peru FTA.

125. Supasiripongchai $N$ (2013) 'The development of the provisions on the protection of Technological Protection Measures (TPMs) in the light of the prospective Thailand-United States Free Trade Agreement (FTA) and its possible impacts on non-infringing uses under copyright exceptions in Thailand: What should be the solution for Thailand?' (2013), 1 Computer and Telecommunications Law Review (CTLR) 21, at 42.

126. Article 16.4 (7) (f) of the US-Singapore FTA and Article 17.4(7) (e) and (f) of the US-Australia FTA.

127. Article 16.4 (7) (e) of the US-Singapore FTA and Article 17.4(7) (e) and (f) of the US-Australia FTA

128. International Federation of the Phonographic Industry (IFPI) (2003) 'The WIPO treaties: Protection of rights management information.

129. Koempel $F$ (2005) 'Digital right management' (2005), 11(8) Computer and Telecommunications Law Review 239, at 240; See also Nimmer, D, 'Puzzles of the Digital Millennium Copyright Act' (1999), 46 Journal of the Copyrigh Society of the USA 401, at 436; International Confederation of Societies of Authors and Composers (CISAC) (2009) Annual report 2009.

130. Gervais D (2001) E-commerce and intellectual property: Lock-it up or license, 6 International Intellectual Property Law and Policy 87.

131. Article 19 (1)(i) of the WPPT

132. Article 19(1)(ii) of the WPPT.

133. Article 19(1)(ii) of the WPPT.

134. Article 16.4(8)(a) of the US-Singapore FTA; Article 17.4(8)(a) of the USAustralia FTA; and Article 17.7(6)(a) of the US-Chile FTA.

135. Article 19(2) of the WPPT.

136. Article 17.4(8) (c) of the US-Australia FTA; Article 16.4(8)(b) of the US Singapore FTA; and Article 17.7(6)(b) of the US-Chile FTA.

137. The final paragraph of Article 17.4(8) (c) of the US-Australia FTA; Article 16.4(8)(b) of the US-Singapore FTA; and Article 17.7(6)(b) of the US-Chile FTA; See also Article 5.8 (2) of the draft of the EU-ASEAN FTA, Intellectual Property Chapter.
138. Dusollier S (2003) 'Some reflections on copyright management information and moral rights', 25 Columbia Journal of Law and the Arts 377 , at 380 .

139. MacQueen H (2009) 'Appropriate for the digital age?: Copyright and the Internet', in Waelde, C and Edwards, L, Law and the Internet: Regulating Cyberspace, (Hart Publishing, Oxford 2009), at 205; See also MacQueen, H, Waelde, C, and Laurie, G, Contemporary intellectual property: Law and policy, (1st edn, Oxford University Press, Oxford 2007), at 190.

140. Recital 56 of Directive 2001/29/EC of the European Parliament and of the Council of 22 May 2001 on the harmonisation of certain aspects of copyright and related rights in the information society.

141. Article 17.4(8) (c) of the US-Australia FTA; Article 16.4(8)(b) of the USSingapore FTA; and Article 17.7(6)(b) of the US-Chile FTA.

142. Article 19(2) of the WPPT.

143. Article 5.8(2) of the draft of the EU-ASEAN FTA, Intellectual Property Chapter accessible at http://www.ip-watch.org/weblog/wp-content/uploads/2009/02/ eu-proposal-asean.doc or http://www.bilaterals.org/IMG/doc/EU-ASEAN IPR_Draft.doc [Accessed April 20, 2014].

144. Article 17.4(8)(c) of the US-Australia FTA; Article 16.4(8)(b) of the USSingapore FTA; and Article 17.7(6)(b) of the US-Chile FTA.

145. Article 19(2) of the WPPT

146. International Federation of the Phonographic Industry (IFPI) (2003) The WIPO treaties: Protection of rights management information.

147. Ginsburg J (2001) Have moral rights come of (digital) age in the United States (2001), 19 Cardozo Arts and Entertainment Law Journal 9, at 11.

148. Section 15(1) of the Thai Copyright Act 1994

149. Ginsburg J (2001) Have moral rights come of (digital) age in the United States 19 Cardozo Arts and Entertainment Law Journal, 10 and 12.

150. Dusollier S (2003) 'Some reflections on copyright management information and moral rights 25 Columbia Journal of Law and the Arts 377, at 389.

151. Article 19 (1) of the WPPT.

152. Article 16.4(8) (a) of the US-Singapore FTA; Article 17.4(8)(a) of the US Australia FTA; and Article 17.7(6)(a) of the US-Chile FTA.

153. Nimmer D (1999) Puzzles of the Digital Millennium Copyright Act, 46 Journal of the Copyright Society of the USA 401, at 436 .

154. Section 52 of the Thai Copyright Act 1994.

155. Article 5.8(1)(a) and (b) of the draft of the EU-ASEAN FTA, Intellectual Property Chapter.

156. The final paragraph of Article 5.8(1) of the draft of the EU-ASEAN FTA, Intellectual Property Chapter.

157. Article 17(1) of the WPPT and Article 14(5) of TRIPs Agreement.

158. Article 16.4(4) of the US-Singapore FTA and Article 17.6 (7) of the US-Chile FTA. 